\title{
Microstructural and Mechanical Properties of $\beta$-Type Ti-Nb-Sn Biomedical Alloys with Low Elastic Modulus
}

\author{
Peiyou Li ${ }^{1, * \mathbb{D}}$, Xindi Ma ${ }^{2}$, Duo Wang ${ }^{1}$ and Hui Zhang ${ }^{1}$ \\ 1 School of Materials Science and Engineering, Shaanxi University of Technology, Hanzhong 723001, China; \\ wangduo2002@126.com (D.W.); Zhanghui_shaanxi@163.com (H.Z.) \\ 2 School of Materials Science and Engineering, Shanghai University, Shanghai 200444, China; \\ Melodyxd@126.com \\ * Correspondence: lipeiyou112@163.com; Tel./Fax: +86-0916-2641711
}

Received: 22 May 2019; Accepted: 21 June 2019; Published: 25 June 2019

check for updates

\begin{abstract}
The microstructural and mechanical properties of $\beta$-type $\mathrm{Ti}_{85-x} \mathrm{Nb}_{10+x} \mathrm{Sn}_{5}(x=0,3,6$, 10 at.\%) alloys with low elastic modulus were investigated. The experimental results show that the $\mathrm{Ti}_{85} \mathrm{Nb}_{10} \mathrm{Sn}_{5}$ and $\mathrm{Ti}_{75} \mathrm{Nb}_{20} \mathrm{Sn}_{5}$ alloys are composed of simple $\alpha$ and $\beta$ phases, respectively; the $\mathrm{Ti}_{82} \mathrm{Nb}_{13} \mathrm{Sn}_{5}$ and $\mathrm{Ti}_{79} \mathrm{Nb}_{16} \mathrm{Sn}_{5}$ alloys are composed of $\beta$ and $\alpha$ " phases. The content of martensite phase decreases with the increase of $\mathrm{Nb}$ content. The $\mathrm{Ti}_{82} \mathrm{Nb}_{13} \mathrm{Sn}_{5}$ and $\mathrm{Ti}_{79} \mathrm{Nb}_{16} \mathrm{Sn}_{5}$ alloys show an inverse martensitic phase transition during heating. The $\mathrm{Ti}_{85} \mathrm{Nb}_{10} \mathrm{Sn}_{5}$ and $\mathrm{Ti}_{82} \mathrm{Nb}_{13} \mathrm{Sn}_{5}$ alloys with the small residual strain exhibit the good superelastic properties in 10-time cyclic loading. The reduced elastic modulus $\left(E_{\mathrm{r}}\right)$ of the $\mathrm{Ti}_{75} \mathrm{Nb}_{20} \mathrm{Sn}_{5}$ alloy (61 GPa) measured by using the nanoindentation technique is 2-6 times of that of human bone $(10-30 \mathrm{GPa})$, and is smaller than that of commercial Ti-6Al-4V biomedical alloy (120 GPa). The $\mathrm{Ti}_{75} \mathrm{Nb}_{20} \mathrm{Sn}_{5}$ alloy can be considered as a novel biomedical alloy. The wear resistance $\left(H / E_{\mathrm{r}}\right)$ and anti-wear capability $\left(H^{3} / E_{\mathrm{r}}{ }^{2}\right)$ values of the four alloys are higher than those of the CP-Ti alloy (0.0238), which indicates that the present alloys have good wear resistance and anti-wear capability.
\end{abstract}

Keywords: $\mathrm{Ti}-\mathrm{Nb}-\mathrm{Sn}$ biomedical alloy; mechanical properties; superelastic properties; elastic modulus

\section{Introduction}

At present, stainless steel, cobalt-chromium ( $\mathrm{Co}-\mathrm{Cr})$ alloy, and titanium alloys are widely used in biomedical alloys [1]. The elastic modulus of medical stainless steel, $\mathrm{Cr}-\mathrm{Co}$ alloys, and titanium alloys as implants are $220 \mathrm{GPa}, 230 \mathrm{GPa}$ and $110 \mathrm{GPa}$, respectively, higher than those of human bone (10-30 GPa) [2]. When the higher elastic modulus of the biomedical alloys do not match the elastic modulus of the human bone around the implant, and can easily cause stress shielding, thus affecting the health of the patient [3-5]. In addition, biomedical alloys require high specific strength for hard tissue implants [2]. Therefore, in the development of biomedical alloys, many researchers are committed to developing Ti alloys with low elastic modulus and high specific strength. In fact, Ti biomedical alloys have not only low elastic modulus and high specific strength, but also low density, good corrosion resistance and good biocompatibility [6-10]. The biomedical $\alpha$-type pure titanium $(\mathrm{CP}-\mathrm{Ti})$, and $(\alpha+\beta)$-type Ti-6Al-4V alloys have the unique therapeutic effects in the field of hard tissue implantation and soft tissue interventional therapy [3,11]. Compared with CP-Ti alloy, Ti-6Al-4V alloy has high strength, corrosion resistance and high hardness $[2,12,13]$. However, the release of the toxic elements $\mathrm{Al}$ and $\mathrm{V}$ can lead to long-term health problems, such as neurological diseases and Alzheimer's disease $[14,15]$. As the elastic modulus of Ti-6Al-4V alloy easily causes stress shielding, 
affecting the health of patients [2]. In recent years, as alternatives to Ti-6Al-4V alloys, non-toxic titanium alloys with lower elastic modulus and without containing the elements $\mathrm{Al}$ and $\mathrm{V}$ like $\mathrm{Ti}-\mathrm{Nb}$ [16-20], Ti-Fe [21,22], Ti-Mo [23,24], Ti-Ta [25], Ti-Zr [26,27]-based alloys were reported. Among them, the $\mathrm{Ti}-\mathrm{Nb}$-based alloys have low elastic modulus, shape memory behavior, and hyperelasticity, so they are favored by biomedical materials researchers [16-20,28-31]. The shape memory effect of Ti-Nb alloys is attributed to the reversible martensite transformation between $\alpha$ " martensite and the parent phase. The martensite transformation temperature and shape memory behavior of $\mathrm{Ti}-\mathrm{Nb}$ alloys mainly depend on the composition [28-31]. In binary $\mathrm{Ti}-\mathrm{Nb}$ alloy, the martensite transformation temperature decreases with the increase of $\mathrm{Nb}$ content [29]. The elements added to broaden the composition range of binary $\mathrm{Ti}-\mathrm{Nb}$ alloy are mainly $\mathrm{Sn}, \mathrm{Ta}, \mathrm{Pd}, \mathrm{Zr}, \mathrm{Mo}$ and $\mathrm{Cu}$, which can adjust the transformation temperature of martensite, and can improve the mechanical properties and shape memory ability of alloys $[2,9,10,30,32]$. These added elements are harmless to the human body, and in fact, some of these elements are necessary trace elements for the human body $[2,5,10]$. In addition, the reported added elements can stabilize the $\beta$ phase, reduce the elastic modulus of $\mathrm{Ti}-\mathrm{Nb}$ alloy, improve the strength of the alloy, and maintain good ductility $[9,10,15,17,18,20,31,32]$.

When the mass percentage of $\mathrm{Nb}$ in binary $\mathrm{Ti}-\mathrm{Nb}$ alloy is $14-26$ mass $\%$, the phases of $\mathrm{Ti}-\mathrm{Nb}$ alloys are composed of martensite and $\beta$ phases; when the mass percentage of $\mathrm{Nb}$ is $26-34$ mass $\%$, and the phases of $\mathrm{Ti}-\mathrm{Nb}$ alloys are composed of martensite, $\beta$ phase and $\omega$ phase [6]. However, when the mass percentage of $\mathrm{Nb}$ content is $34-40$ mass $\%$, there is only $\beta$ phase in Ti-Nb alloy [6]. When the reversible martensite transformation between martensite and parent phase can exist, the alloy exhibits shape memory behavior [6]. Therefore, to study the shape memory behavior of $\mathrm{Ti}-\mathrm{Nb}$ alloy, the mass percentage of $\mathrm{Nb}$ element should be less than 34 mass $\%$; to obtain a relatively stable $\beta$-type phase content, the mass percentage of $\mathrm{Nb}$ content is generally greater than 34 mass\% [6]. In ternary $\mathrm{Ti}-\mathrm{Nb}-\mathrm{Sn}$ alloys, the addition of $\mathrm{Sn}$ can adjust the mass percentage of $\mathrm{Ti}$ and $\mathrm{Nb}$, and then adjust the content of martensite, allow the study of the shape memory behavior and/or superelasticity of different components, and the mechanical properties of $\beta$-type Ti-Nb-Sn alloys [31,33-35]. Wang [30] reported that in ternary $\mathrm{Ti}-\mathrm{Nb}-\mathrm{Sn}$ alloys, the content of martensite decreases with the increase of $\mathrm{Sn}$ content, and decreases with the decrease of corresponding Ti content, indicating that stable $\beta$-type $\mathrm{Ti}-\mathrm{Nb}-\mathrm{Sn}$ alloys can be obtained by adjusting the Ti and $\mathrm{Sn}$ contents. In fact, in the study of bone tissue implants, the Ti-25Nb-11Sn (wt.\%) or $\mathrm{Ti}_{78.7} \mathrm{Nb}_{15.8} \mathrm{Sn}_{5.5}$ (at.\%) alloys have good bone tissue compatibility, equivalent to that of Ti-6Al-4V alloy [36]. Importantly, both $\mathrm{Nb}$ and $\mathrm{Sn}$ ions are harmless to human body $[2,5,35,36]$. For the $\mathrm{Ti}_{78.7} \mathrm{Nb}_{15.8} \mathrm{Sn}_{5.5}$ alloy [36], the precipitation of $\mathrm{Ti}_{3} \mathrm{Sn}$ intermetallic compound in the second phase can be inhibited at low Sn content to stabilize the $\beta$ phase. When the $\mathrm{Nb}$ content decreases, the Ti content increases, and the content of Sn remains unchanged, the martensite phase and $\mathrm{Ti}_{3} \mathrm{Sn}$ phase may increase, which results in a low stability of the $\beta$ phase and high elastic modulus. When the $\mathrm{Nb}$ content increases and the Ti content decreases, and the Sn content remains unchanged, the martensite phase and $\mathrm{Ti}_{3} \mathrm{Sn}$ phase will decrease, which results in a high stability of the $\beta$ phase and a low elastic modulus. For the $\mathrm{Ti}_{78.7} \mathrm{Nb}_{15.8} \mathrm{Sn}_{5.5}$ alloy, the effect of $\mathrm{Nb}$ and Ti contents on the content of martensitic phase or $\mathrm{Ti}_{3} \mathrm{Sn}$ second phase, as well as the martensitic transformation temperature and mechanical properties needs further study to provide a reference for selecting biomedical alloys. In fact, the mass percentage of $\mathrm{Nb}$ in ternary $\mathrm{Ti}_{85} \mathrm{Nb}_{10} \mathrm{Sn}_{5}$ (at.\%) is 16.61 mass\%, which locates in the range of 14-26\% [6]; according to the results of Hon's experiments [6], the $\mathrm{Ti}_{85} \mathrm{Nb}_{10} \mathrm{Sn}_{5}$ alloy containing martensite phase may have hyperelastic behavior. In this paper, $\mathrm{Ti}_{85} \mathrm{Nb}_{10} \mathrm{Sn}_{5}$ (at.\%) was chosen as the model alloy, and an alloy with the composition $\mathrm{Ti}_{85-x} \mathrm{Nb}_{10+x} \mathrm{Sn}_{5}(x=0,3,6,10$ at.\%) was designed, in which, when $x=3$, the $\mathrm{Ti}_{79} \mathrm{Nb}_{16} \mathrm{Sn}_{5}$ component is similar to the $\mathrm{Ti}_{78.7} \mathrm{Nb}_{15.8} \mathrm{Sn}_{5.5}$ component. The main purpose was to study the effect of martensite or $\mathrm{Ti}_{3} \mathrm{Sn}$ contents on martensite transformation temperature, hyperelasticity, and on elastic modulus and hardness, based on the increase of $\mathrm{Nb}$ content and the corresponding decrease of Ti content in $\mathrm{Ti}_{85} \mathrm{Nb}_{10} \mathrm{Sn}_{5}$ alloys. The experimental results can provide a reference for the selection of $\mathrm{Ti}-\mathrm{Nb}-\mathrm{Sn}$ biomedical alloys. 


\section{Experimental Procedure}

Various combinations of pure $\mathrm{Ti}, \mathrm{Nb}$, and $\mathrm{Sn}$ (purity of $99.9 \%$ or higher) were used to prepare ingots of four Ti-Nb-Sn alloys with nominal compositions $\mathrm{Ti}_{85} \mathrm{Nb}_{10} \mathrm{Sn}_{5}, \mathrm{Ti}_{82} \mathrm{Nb}_{13} \mathrm{Sn}_{5}, \mathrm{Ti}_{79} \mathrm{Nb}_{16} \mathrm{Sn}_{5}$, and $\mathrm{Ti}_{75} \mathrm{Nb}_{20} \mathrm{Sn}_{5}$ (at.\%) under a high vacuum $\left(3 \times 10^{-3} \mathrm{~Pa}\right)$ using a magnetically controlled tungsten arc-melting furnace (Shenyang Scientific Instruments Co., Ltd., Chinese Academy of Sciences, Shenyang, China) in an argon atmosphere. The raw materials $\mathrm{Ti}, \mathrm{Nb}$ and $\mathrm{Sn}$ are bulk, and the range of sizes was from $5 \times 5 \times 5 \mathrm{~mm}^{3}$ to $20 \times 20 \times 20 \mathrm{~mm}^{3}$. These raw materials were obtained from Beijing Xing rong yuan Technology Co., Ltd. (Beijing, China). The calculated quantities of raw materials were weighed using an analytical balance with a precision of $0.1 \mathrm{mg}$. For example, for the $\mathrm{Ti}_{85} \mathrm{Nb}_{10} \mathrm{Sn}_{5}$ alloy, the quantity of Ti is $21.8325 \mathrm{~g}$, that of $\mathrm{Nb}$ is $4.9840 \mathrm{~g}$ and that of $\mathrm{Sn}$ is $3.1836 \mathrm{~g}$. Such a small mass is taken from the bulk raw materials using iron pliers. Minor mass changes were ground using a grinding wheel, in accordance with the calculated mass. After mixing the raw materials, a total of $30 \mathrm{~g}$ of raw materials were put into a water-cooled crucible to smelt into alloy ingots. As the melting point of $\mathrm{Nb}$ is high, the solution in contact with the crucible cools rapidly, and the atom diffusion of $\mathrm{Nb}$ in the solution is slow. When the number of smelting cycles is small, the composition of the alloy is non-uniform. To ensure the uniformity of the chemical composition of the ingots, all the ingots were smelted more than 7 times. Rod-like samples with a diameter of $3 \mathrm{~mm}$, and a length of more than $10 \mathrm{~mm}$ were cut from the ingots with the diameter of about $25 \mathrm{~mm}$ and the height of about $11 \mathrm{~mm}$. The samples for mechanical and structural analysis were cut from the rod-shaped samples by using a slow steel saw. The surfaces of thin sheets with diameter of $3 \mathrm{~mm}$ were polished using standard metallographic procedures, consisting of grinding up to 2000 grit with $\mathrm{SiC}$ paper and polishing with a colloidal silica suspension. For observing the microstructure, the surfaces of polished samples need to be corroded. This was accomplished with a mixed solution of $\mathrm{HF}, \mathrm{HNO}_{3}$ and $\mathrm{H}_{2} \mathrm{O}$, and the corresponding volume ratio is 1:4:16. The microstructures of the prepared samples were observed by optical microscope $(\mathrm{OM})$. The cross-sections of samples with a diameter of $3 \mathrm{~mm}$ are observed using a Rigaku $\mathrm{D} \backslash \max -2550$ X-ray diffractometer (XRD, Rigaku Company, Tokyo, Japan), at an operating voltage of $30 \mathrm{KV}$, using $\mathrm{Cu}$-Ka radiation. The chemical compositions of alloys were measured by scanning electron microscopy (SEM, JSM-6390LV, JEOL, Peabody, MA, USA) with an energy dispersive spectrometer (EDS). To obtain more accurate chemical components, five points were scanned in different regions, and the values of chemical components obtained were the average of five measurements.

The phase transformation temperatures of the samples with a diameter of $3 \mathrm{~mm}$ weighing $20-50 \mathrm{mg}$ was measured by differential scanning calorimetry (DSC) with heating and cooling rates of $0.33 \mathrm{~K} \cdot \mathrm{s}^{-1}$, using a Perkin Elmer DSC 7 instrument (PerkinElmer, Waltham, MA, USA). To prevent the instability of the sample during compression, the ratio of length to diameter is 1.5 times to 2 times. The cylindrical $\mathrm{Ti}-\mathrm{Nb}-\mathrm{Sn}$ samples with a diameter of $3.0 \mathrm{~mm}$ and height of $\sim 5.0 \mathrm{~mm}$ were prepared by subjecting them to uniaxial compression testing at room temperature. The two sections of the samples are smooth and parallel, to reduce the friction between the pressure head and the end face of the sample. The uniaxial compression testing was performed at room temperature using a CMT5105 electronic testing machine (Metis Industrial Systems (China) Co., Ltd., Shanghai, China), at a strain rate of $2.5 \times 10^{-4} \mathrm{~s}^{-1}$. The quantitative data were all measured for three times, and the average results are shown. The cycle loading and unloading experiments were also carried out on this instrument at a strain rate of $2.5 \times 10^{-4} \mathrm{~s}^{-1}$. The Vickers hardness (HV) measurement of polished samples was performed using an HVS-10Z/LCD hardness testing machine (Shanghai Gaozhi Precision Instrument Co., Ltd., Shanghai, China) with a load of $20 \mathrm{kgf}$ for $10 \mathrm{~s}$. To get the HV value of the alloy more accurately, each sample was tested ten times, and the reported value was the average of 10 measurements.

Elastic modulus is an important mechanical property parameter for biomedical alloys, so accuracy is required in elastic modulus measurements. On the stress-strain curve, the elastic modulus of alloys can also be obtained by the ratio of stress to strain, but, as the elastic modulus of the instrument itself, the elastic modulus calculated by the stress-strain curve includes the elastic modulus of the instrument and the elastic modulus of the alloy, which results in the fact that the elastic modulus 
error for the $\mathrm{Ti}-\mathrm{Nb}-\mathrm{Sn}$ alloy is large. This large elastic modulus error looses its reference value for biomaterials. The error of elastic modulus measurements between the nano-indentation technique and ultrasonic testing is small [8,24]. Therefore, the elastic modulus of Ti-Nb-Sn alloys was measured by the nano-indentation technique, and the hardness of the samples was also measured at the same time. The nano-indentation tests were performed by a Hystron-T1980 TriboIndentor system (Beijing Obel Scientific Instruments Co., Ltd. Beijing, China) equipped with a Berkovich indenter (Bruker, Germany). The indentation marks (indents) were made using an applied load of $8000 \mu \mathrm{N}$, loading rate of $1.6 \mathrm{mN} \cdot \mathrm{s}^{-1}$, and dwell time of $5 \mathrm{~s}$. The reduced elastic modulus $\left(E_{\mathrm{r}}\right)$ and hardness $(H)$ values were calculated automatically using the TriboScan ${ }^{\mathrm{Tm}}$ software (Boston University, Boston, MA, USA). To reduce test errors, 10 sample nanoindentation tests were carried, and the reported data is the average of 10 tests. To ensure the correctness of the measured results, the surface of each sample was polished to a mirror-finish. Based on a Berkovich indenter, the calculated $E_{\mathrm{r}}$ values were used [24]:

$$
E_{r}=\frac{\sqrt{\pi}}{2 \sqrt{A\left(h_{c}\right)}} S
$$

where $S$ is the stiffness, and $A\left(h_{\mathrm{c}}\right)$ represents the contact area.

\section{Results and Discussion}

\subsection{Phase and Microstructure of Ti-Nb-Sn Alloys}

Figure 1 shows the XRD patterns of as-cast $\mathrm{Ti}_{85-\mathrm{x}} \mathrm{Nb}_{10+\mathrm{x}} \mathrm{Sn}_{5}(\mathrm{x}=0,3,6$, and 10 at.\%) alloys. The $\mathrm{Ti}_{85} \mathrm{Nb}_{10} \mathrm{Sn}_{5}$ alloy is composed of $\alpha$ phase and a small amount of $\mathrm{Ti}_{3} \mathrm{Sn}$ phase; the $\mathrm{Ti}_{82} \mathrm{Nb}_{13} \mathrm{Sn}_{5}$ and $\mathrm{Ti}_{79} \mathrm{Nb}_{16} \mathrm{Sn}_{5}$ alloys are composed of $\beta$ and $\alpha$ " phases; the $\mathrm{Ti}_{75} \mathrm{Nb}_{20} \mathrm{Sn}_{5}$ alloy is composed of simple $\beta$ phase. The addition of $\mathrm{Nb}$ stabilizes the $\beta$ phase. The relative volume fraction of the matrix and the second phase can be calculated quantitatively using the XRD patterns.

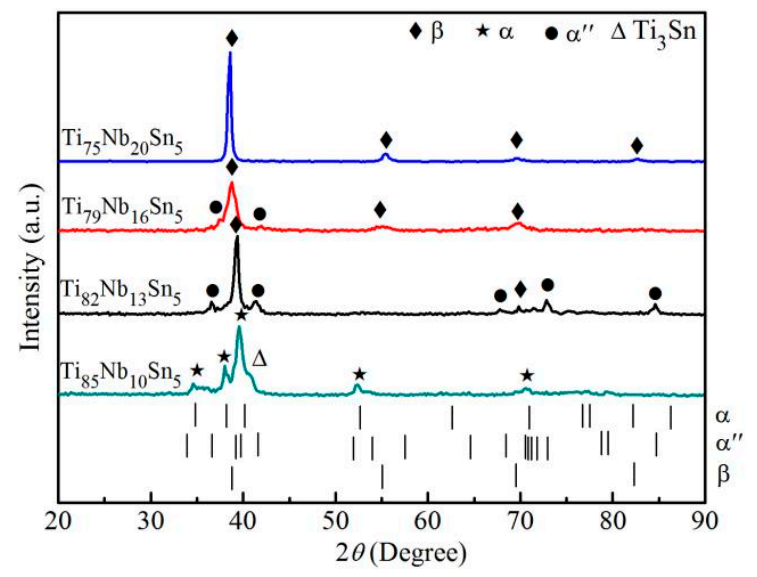

Figure 1. XRD patters of $\mathrm{Ti}_{85-x} \mathrm{Nb}_{10+x} \mathrm{Sn}_{5}(x=0,3,6$, and 10 at.\%) alloys.

The main reported method to calculate the volume fraction of the phase is the integral-area method of the diffraction peak $[17,18,37]$. To ensure that the diffraction intensity of XRD energy spectrum and the integral area of diffraction peak of different samples are comparable, the cross section areas of the tested samples were the same, and the XRD energy spectrum is measured under the same test conditions. When the cross section area of Ti-Nb-Sn samples for the XRD energy spectrum is $3 \mathrm{~mm}$, and other same test conditions, the diffraction intensity and integral area of diffraction peak for the different samples are comparable. The integrated areas of diffraction peaks for $\beta$ and $\alpha$ " phases in 
Figure 1 were determined by using the peak-fitting program $[17,18,37]$. The volume fraction $\left(V_{\mathrm{f}}\right)$ of $\beta$ and $\alpha^{\prime \prime}$ phases were calculated by using Equations (2) and (3) [37,38],

$$
\begin{gathered}
V_{\mathrm{f}\left(\alpha^{\prime \prime}\right)}=\frac{A_{\alpha^{\prime \prime}}}{A_{\alpha^{\prime \prime}}+A_{\beta}} \\
V_{\mathrm{f}(\beta)}=\frac{A_{\beta}}{A_{\alpha^{\prime \prime}}+A_{\beta}}
\end{gathered}
$$

where, $V_{\mathrm{f}\left(\alpha^{\prime \prime}\right)}$ and $V_{\mathrm{f}(\beta)}$ are the volume fractions, and $A_{\alpha^{\prime \prime}}$ and $A_{\beta}$ are the total integrated area, corresponding to $\alpha^{\prime \prime}$ and $\beta$ phases, respectively. The calculated volume fractions of the $\beta$ and $\alpha^{\prime \prime}$ phases according to the integrated area of diffraction peaks for the $\beta$ and $\alpha^{\prime \prime}$ phases in Figure 1, are listed in Table 1. The $V_{\mathrm{f}\left(\alpha^{\prime \prime}\right)}$ values of the $\alpha^{\prime \prime}$ phase in $\mathrm{Ti}_{82} \mathrm{Nb}_{13} \mathrm{Sn}_{5}$ and $\mathrm{Ti}_{79} \mathrm{Nb}_{16} \mathrm{Sn}_{5}$ alloys are $26.5 \%$ and $(7.1 \%)$, respectively, which are larger than that of $\mathrm{Ti}_{75} \mathrm{Nb}_{20} \mathrm{Sn}_{5}(0.0 \%)$ alloy, respectively. Accordingly, the relative content of $\alpha^{\prime \prime}$ phase decreases with decrease of $\mathrm{Nb}$ content, and with the increase of corresponding $\beta$ phase; the $\mathrm{Ti}_{85} \mathrm{Nb}_{10} \mathrm{Sn}_{5}$ and $\mathrm{Ti}_{75} \mathrm{Nb}_{20} \mathrm{Sn}_{5}$ alloys exhibit a single stable $\alpha$ and $\beta$ phases, respectively.

Table 1. Measured mechanical properties of various alloys, including the initial stress $\left(\sigma_{\mathrm{ms}}\right)$, finished stress $\left(\sigma_{\mathrm{mf}}\right)$, and finished strain $\left(\varepsilon_{\mathrm{mf}}\right)$ of martensitic transformation, $0.2 \%$ offset yield stress $\left(\sigma_{0.2}\right)$, Vickers hardness (HV), elastic energy $\left(W_{\mathrm{e}}\right)$; volume fractions of $\alpha^{\prime \prime}\left(V_{\alpha^{\prime \prime}}\right)$ and $\beta\left(V_{\beta}\right)$ phases; molybdenum

\begin{tabular}{|c|c|c|c|c|c|c|c|c|c|c|c|}
\hline Alloys & $\begin{array}{c}\sigma_{\mathrm{ms}} \\
(\mathrm{MPa})\end{array}$ & $\underset{(\mathrm{MPa})}{\sigma_{\mathrm{mf}}}$ & $\begin{array}{l}\varepsilon_{\mathrm{mf}} \\
(\%)\end{array}$ & $\begin{array}{c}\sigma_{0.2} \\
(\mathrm{MPa})\end{array}$ & $\begin{array}{l}\mathcal{E}_{0.2} \\
(\%)\end{array}$ & $\mathrm{HV}$ & $\begin{array}{c}W_{\mathrm{e}} \times 10^{6} \\
\left(\mathrm{~J} \cdot \mathrm{m}^{-3}\right)\end{array}$ & $\begin{array}{l}V_{\alpha^{\prime \prime}} \\
(\%)\end{array}$ & $\begin{array}{l}V_{\beta} \\
(\%)\end{array}$ & $M o_{\text {eq }}$ & $\begin{array}{c}T_{\mathrm{A}} \\
\left({ }^{\circ} \mathrm{C}\right)\end{array}$ \\
\hline $\mathrm{Ti}_{85} \mathrm{Nb}_{10} \mathrm{Sn}_{5}$ & 352 & 509 & 4.48 & 787 & 6.84 & 230 & - & - & - & 7.83 & - \\
\hline $\mathrm{Ti}_{82} \mathrm{Nb}_{13} \mathrm{Sn}_{5}$ & 256 & 574 & 5.56 & 772 & 9.46 & 226 & - & 26.5 & 73.5 & 9.02 & 169 \\
\hline $\mathrm{Ti}_{79} \mathrm{Nb}_{16} \mathrm{Sn}_{5}$ & 370 & 508 & 3.21 & 611 & 5.30 & 220 & 1.65 & 7.1 & 92.9 & 10.14 & 177 \\
\hline $\mathrm{Ti}_{75} \mathrm{Nb}_{20} \mathrm{Sn}_{5}$ & - & - & - & 435 & 3.71 & 218 & 6.53 & 0.0 & 100 & 11.56 & - \\
\hline
\end{tabular}
equivalent $\left(\mathrm{Mo} o_{\mathrm{eq}}\right)$; reverse martensite transformation temperature $\left(T_{\mathrm{A}}\right)$ in DSC curves.

Based on the ESD analysis, the true chemical compositions of the five alloys are $\mathrm{Ti}_{85.32} \mathrm{Nb}_{10.1} \mathrm{Sn}_{4.58}$, $\mathrm{Ti}_{82.96} \mathrm{Nb}_{12.73} \mathrm{Sn}_{4.31}, \mathrm{Ti}_{79.06} \mathrm{Nb}_{16.7} \mathrm{Sn}_{4.24}$ and $\mathrm{Ti}_{75.32} \mathrm{Nb}_{20.52} \mathrm{Sn}_{4.16}$, respectively. Compared with the nominal composition, the atomic percentages of $\mathrm{Ti}$ and $\mathrm{Nb}$ elements are larger than those of the nominal composition, while the atomic percentages of $\mathrm{Sn}$ elements decrease gradually with the increase of $\mathrm{Nb}$ content, and are less than 5 at. $\%$ of the nominal composition. As the boiling point $\left(2260^{\circ} \mathrm{C}\right)$ of $\mathrm{Sn}$ is lower than the melting point $\left(2468^{\circ} \mathrm{C}\right)$ of $\mathrm{Nb}$, the volatilization of $\mathrm{Sn}$ is easier than those of $\mathrm{Ti}$ and $\mathrm{Nb}$ during the alloy smelting process. In addition, each smelting time of alloy with the high $\mathrm{Nb}$ content is longer than that of alloy with the low $\mathrm{Nb}$ content, which leads to a longer volatilization time for the $\mathrm{Sn}$ element, resulting in a low $\mathrm{Sn}$ concentration of alloys with high $\mathrm{Nb}$ content. Accordingly, based on the results of EDS analysis, the changes of true and nominal components of the alloys provide a reference for industrial applications.

Figure 2 shows the microstructure of Ti-Nb-Sn alloys observed by optical microscope. For the $\mathrm{Ti}_{85} \mathrm{Nb}_{10} \mathrm{Sn}_{5}$ alloy, a large amount of needle-like $\alpha$ martensite phase can be found to precipitate in the matrix $\beta$ phase. For the $\mathrm{Ti}_{82} \mathrm{Nb}_{12} \mathrm{Sn}_{5}$ alloy, less needle-like $\alpha$ " martensite phase is precipitated in the matrix $\beta$ phase. As the relative content of $\alpha$ " phase for the $\mathrm{Ti}_{79} \mathrm{Nb}_{16} \mathrm{Sn}_{5}$ alloy is small in Figure 1, the $\alpha^{\prime \prime}$ phase microstructure cannot be found in Figure 2c. The microstructure of single $\beta$ phase for the $\mathrm{Ti}_{75} \mathrm{Nb}_{20} \mathrm{Sn}_{5}$ alloy is exhibited in Figure 2d. The results agree with those of XRD patterns in Figure 1. 

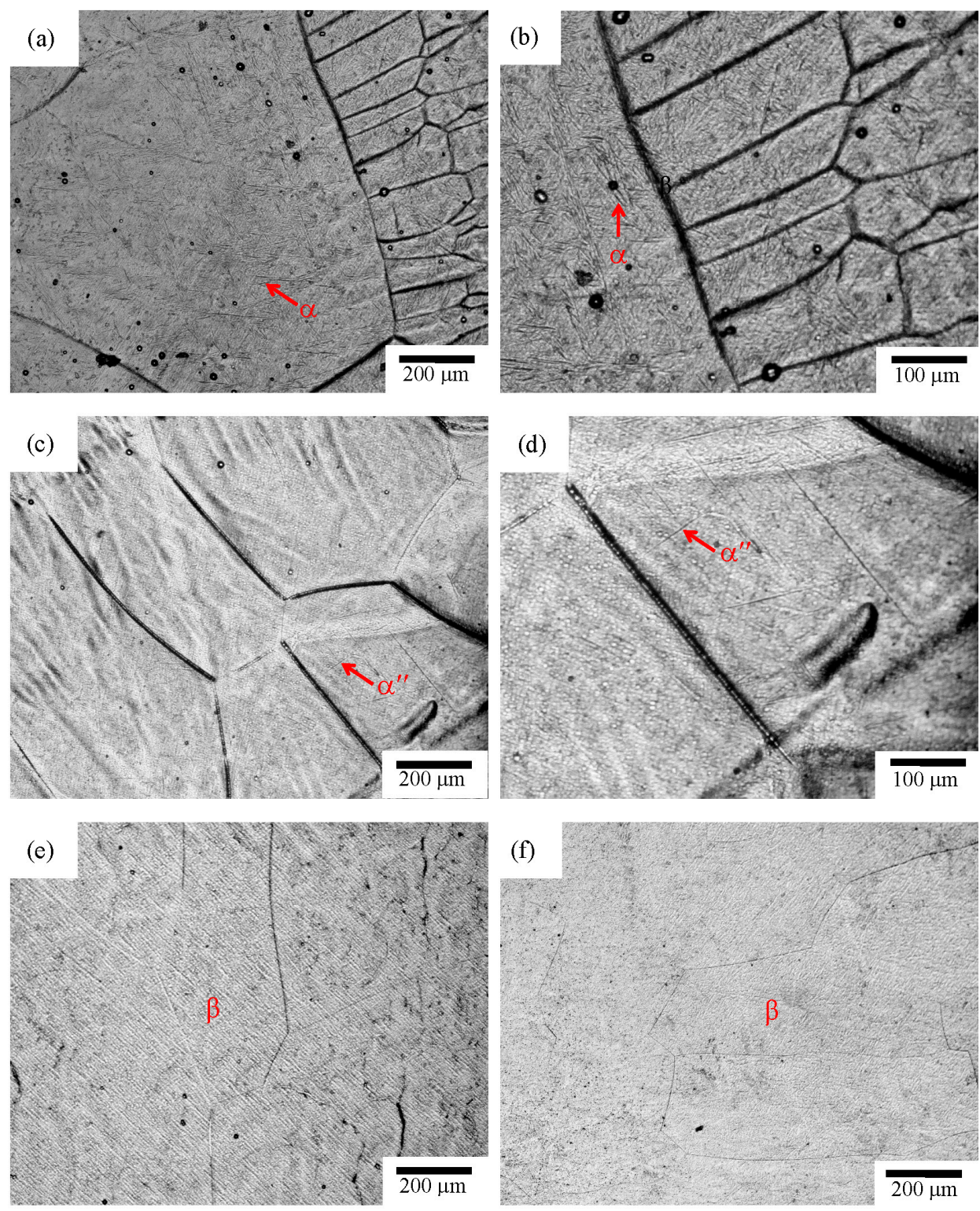

Figure 2. Microstructure of (a) and (b) $\mathrm{Ti}_{85} \mathrm{Nb}_{10} \mathrm{Sn}_{5}$, (c) and (d) $\mathrm{Ti}_{82} \mathrm{Nb}_{13} \mathrm{Sn}_{5}$, (e) $\mathrm{Ti}_{79} \mathrm{Nb}_{16} \mathrm{Sn}_{5}$, and (f) $\mathrm{Ti}_{75} \mathrm{Nb}_{20} \mathrm{Sn}_{5}$ alloys observed by optics microscope.

When the transition metal $\mathrm{Nb}$ is added to Ti alloy, the stabilization of $\beta$ phase can be attributed to the increase of conduction-electron density, which enhances the screening of the ion core [39]. This favors a formation of BCC structure, and consequently increases the stability of the $\beta$-Ti phase [39]. In Ti alloys, when the content of the stable element of the $\beta$ phase is low, the alloy exhibits only $\alpha$ phase; when the content of the added stabilizing element is high, the alloy will have a $(\alpha+\beta)$ or $\left(\alpha^{\prime \prime}+\beta\right)$ microstructure; when further stable element is added, the alloy will present the metastable $\beta$ phase [39].

Therefore, for the $\mathrm{Ti}_{85} \mathrm{Nb}_{10} \mathrm{Sn}_{5}$ alloy, the content of stable $\beta$ phase $\mathrm{Nb}$ is less, and the microstructure of the alloy is only $\alpha$ phase. For the $\mathrm{Ti}_{82} \mathrm{Nb}_{13} \mathrm{Sn}_{5}$ and $\mathrm{Ti}_{79} \mathrm{Nb}_{16} \mathrm{Sn}_{5}$ alloys, when the content of $\mathrm{Nb}$ is further increased, the microstructures of the alloys are composed of $\alpha^{\prime \prime}+\beta$ phases, and $\beta$ phase stability is exhibited. For the $\mathrm{Ti}_{75} \mathrm{Nb}_{20} \mathrm{Sn}_{5}$ alloy, when the content of $\mathrm{Nb}$ is the highest, the alloy is only composed of metastable $\beta$ phase at room temperature. When the content of $\mathrm{Sn}$ is too high, Ti and $\mathrm{Sn}$ can easily form stable intermetallic compounds of $\mathrm{Ti}_{3} \mathrm{Sn}$, which destroys the stability of the $\beta$ phase. When the content of $\mathrm{Sn}$ is low, the content of $\mathrm{Ti}_{3} \mathrm{Sn}$ phase is less, so the $\beta$ phase can be stabilized. In 
addition, although $\mathrm{Sn}$ is a neutral element, the addition of Sn can change the phase transition kinetics of $w$ phase, thus improving the stability of $\beta$ phase [39]. Therefore, in the present $\mathrm{Ti}-\mathrm{Nb}-\mathrm{Sn}$ alloys, when the percentage of $\mathrm{Sn}$ atom is set to $5 \%$, the content of $\mathrm{Nb}$ is increased, and the content of $\mathrm{Ti}$ is decreased accordingly, which inhibits the precipitation of $\mathrm{Ti}_{3} \mathrm{Sn}$ phase, and promotes the stability of the $\beta$ phase.

In multicomponent Ti alloy systems, the stability of the $\beta$-Ti phase can be represented by the molybdenum equivalent $\left(M o_{\text {eq }}\right)$ [39]. The larger the $M o_{\text {eq }}$ value is, the more the stability of $\beta$-Ti phase is. The $M o_{\text {eq }}$ value can be expressed using the following formula [40]:

$$
[\mathrm{Mo}]_{e q}=[\mathrm{Mo}]+1.25[\mathrm{~V}]+0.59[\mathrm{~W}]+0.28[\mathrm{Nb}]+0.22[\mathrm{Ta}]+0.30[\mathrm{Sn}]
$$

where $[x]$ is the concentration of $x$ element in weight percent [40]. Table 1 shows the calculated $M o_{\text {eq }}$ values of Ti-Nb-Sn alloys. The $M o_{\text {eq }}$ values increase from 7.83 of $\mathrm{Ti}_{85} \mathrm{Nb}_{10} \mathrm{Sn}_{5}$ alloy to 11.56 of $\mathrm{Ti}_{75} \mathrm{Nb}_{20} \mathrm{Sn}_{5}$ alloy. In fact, the $M o_{\mathrm{eq}}$ values increase with the increase of $\mathrm{Nb}$ contents, indicating that the stability of $\beta$-Ti phase increases with the increase of $\mathrm{Nb}$ contents. The results agree with those of XRD curves.

\subsection{Phase Transition Temperature of Ti-Nb-Sn Alloys}

In hard tissue implants, martensitic transformation cannot occur within a temperature range that the human body can withstand, because martensitic transformation can change the volume of tissue implants, and the volume change of hard tissue implants will cause secondary injuries to patients. Under special circumstances, the temperature range that human body can bear is between $-50{ }^{\circ} \mathrm{C}$ and $100{ }^{\circ} \mathrm{C}$ (burn or scald). Within this temperature range, the special requirement for hard tissue implants is that there is no martensitic transformation or volume change. Therefore, to better study $\mathrm{Ti}-\mathrm{Nb}-\mathrm{Sn}$ biomedical alloys, the temperature range of phase transformation should include the temperature range that human body can bear in special environment. Accordingly, the temperature range of phase transformation should be set to $-100^{\circ} \mathrm{C}$ to $200{ }^{\circ} \mathrm{C}$.

Figure 3 shows the DSC curves of the phase transition temperature during heating and cooling. When the four alloys are cooled from $200{ }^{\circ} \mathrm{C}$ to $-100{ }^{\circ} \mathrm{C}$, no martensitic transformation occurs; when heated from $-100{ }^{\circ} \mathrm{C}$ to $20{ }^{\circ} \mathrm{C}$, the $\mathrm{Ti}_{85} \mathrm{Nb}_{10} \mathrm{Sn}_{5}$ and $\mathrm{Ti}_{75} \mathrm{Nb}_{20} \mathrm{Sn}_{5}$ alloys do not exhibit reverse martensitic phase transition, while the $\mathrm{Ti}_{82} \mathrm{Nb}_{13} \mathrm{Sn}_{5}$ and $\mathrm{Ti}_{79} \mathrm{Nb}_{16} \mathrm{Sn}_{5}$ alloys show inverse martensitic phase transition, and the phase transition temperatures $\left(T_{\mathrm{A}}\right)$ are $169^{\circ} \mathrm{C}$ and $177^{\circ} \mathrm{C}$, respectively. Because the martensitic transition is not present during heating, thermal phase transformation hysteresis does not exist. In Ti-Nb-Sn alloy, as the $\mathrm{Ti}_{85} \mathrm{Nb}_{10} \mathrm{Sn}_{5}$ and $\mathrm{Ti}_{75} \mathrm{Nb}_{20} \mathrm{Sn}_{5}$ alloys are composed of single $\alpha$ and $\beta$ phases, respectively, there is no martensitic transformation during heating and cooling, indicating that the martensite in Ti-Nb-Sn alloy is independent of single $\alpha$ and $\beta$ phases. As the $\mathrm{Ti}_{82} \mathrm{Nb}_{13} \mathrm{Sn}_{5}$ alloy contains a large number of $\alpha^{\prime \prime}$-Ti phases, the inverse martensite transformation occurs when the alloy is heated from $-100{ }^{\circ} \mathrm{C}$ to $150{ }^{\circ} \mathrm{C}$. However, when the $\mathrm{Ti}_{79} \mathrm{Nb}_{16} \mathrm{Sn}_{5}$ alloy contains a small amount of $\alpha^{\prime \prime}$-Ti phases, the inverse martensite transformation also occurs in the range of heating temperature, which indicates that the inverse martensite transformation is related to the $\alpha^{\prime \prime}-$ Ti phase. Therefore, the $\mathrm{Ti}-\mathrm{Nb}-\mathrm{Sn}$ alloys have no martensitic transformation in the temperature range that human body can bear, indicating that the Ti-Nb-Sn alloys are the good biomedical alloys for implantation. 

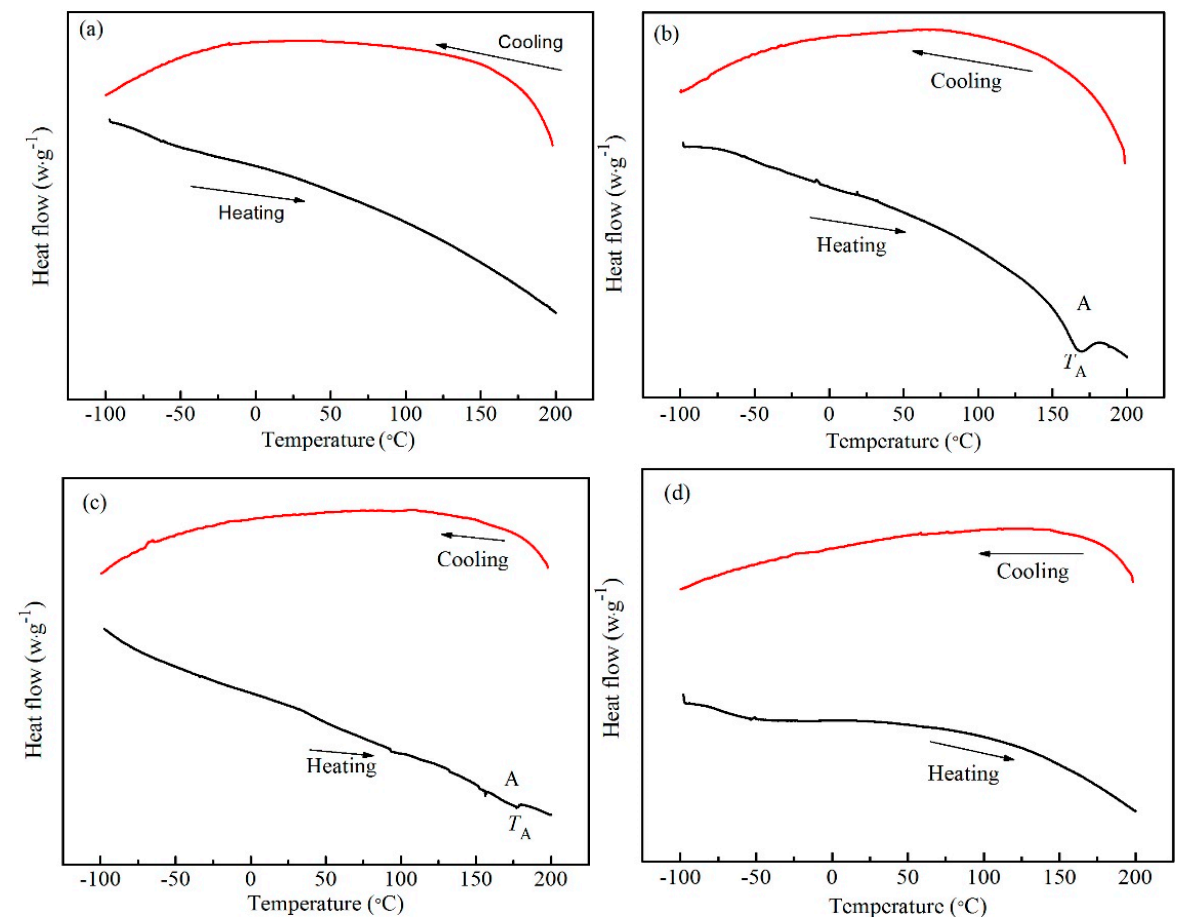

Figure 3. Phase transformation temperature of (a) $\mathrm{Ti}_{85} \mathrm{Nb}_{10} \mathrm{Sn}_{5}$, (b) $\mathrm{Ti}_{82} \mathrm{Nb}_{13} \mathrm{Sn}_{5}$, (c) $\mathrm{Ti}_{79} \mathrm{Nb}_{16} \mathrm{Sn}_{5}$ and (d) $\mathrm{Ti}_{75} \mathrm{Nb}_{20} \mathrm{Sn}_{5}$ alloys in the DSC curves.

\subsection{Mechanical Properties of $\mathrm{Ti}-\mathrm{Nb}-\mathrm{Sn}$ Alloys}

Figure 4 shows the compression stress-strain curves of $\mathrm{Ti}-\mathrm{Nb}-\mathrm{Sn}$ alloys at room temperature. The stress-induced martensite transformation is exhibited in Figure $4 a, b$ for the $\mathrm{Ti}_{85} \mathrm{Nb}_{10} \mathrm{Sn}_{5}$ and $\mathrm{Ti}_{82} \mathrm{Nb}_{13} \mathrm{Sn}_{5}$ alloys, that is, the stress-strain curves show a characteristic two-step yield behavior, which indicates that the two alloys present hyperelastic characteristics at room temperature.
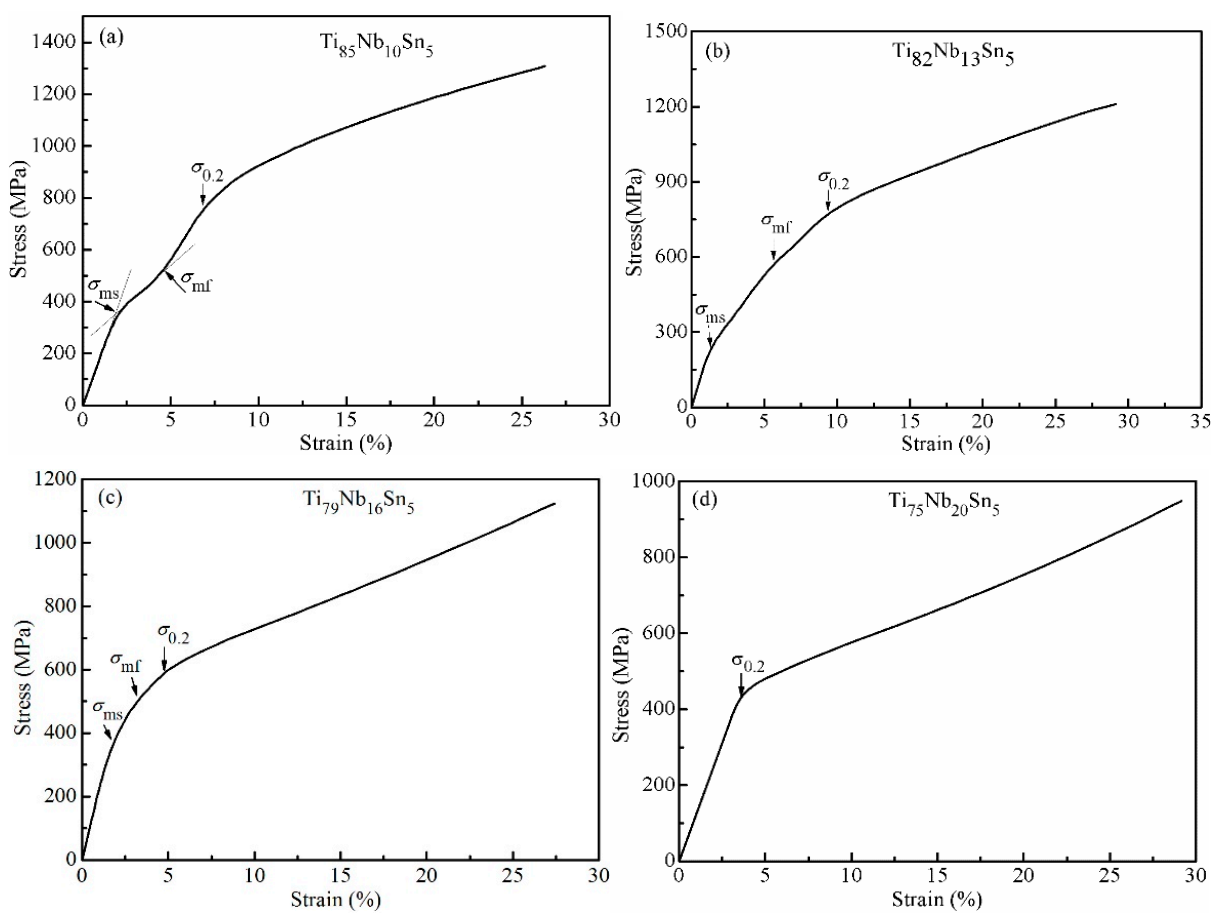

Figure 4. Stress-strain curves of (a) $\mathrm{Ti}_{85} \mathrm{Nb}_{10} \mathrm{Sn}_{5}$, (b) $\mathrm{Ti}_{82} \mathrm{Nb}_{13} \mathrm{Sn}_{5}$, (c) $\mathrm{Ti}_{79} \mathrm{Nb}_{16} \mathrm{Sn}_{5}$ and (d) $\mathrm{Ti}_{75} \mathrm{Nb}_{20} \mathrm{Sn}_{5}$ alloys. 
The initial stress $\left(\sigma_{\mathrm{ms}}\right)$ and strain $\left(\varepsilon_{\mathrm{ms}}\right)$ of martensite transformation, the finished stress $\left(\sigma_{\mathrm{mf}}\right)$ and strain $\left(\varepsilon_{\mathrm{mf}}\right)$ of martensite transformation, the offset $0.2 \%$ yield stress $\left(\sigma_{0.2}\right)$ calculated, and initial plastic strain $\left(\varepsilon_{0.2}\right)$ in the stress-strain curves are listed in Table 1 . The $\sigma_{\mathrm{ms}}$ and $\sigma_{\mathrm{mf}}$ values are $352 \mathrm{MPa}$ and $509 \mathrm{MPa}$ for the $\mathrm{Ti}_{85} \mathrm{Nb}_{10} \mathrm{Sn}_{5}$ alloy, and $256 \mathrm{MPa}$ and $574 \mathrm{MPa}$ for the $\mathrm{Ti}_{82} \mathrm{Nb}_{13} \mathrm{Sn}_{5}$ alloy, respectively. In addition, the $\varepsilon_{0.2}$ values of $\mathrm{Ti}_{85} \mathrm{Nb}_{10} \mathrm{Sn}_{5}$ and $\mathrm{Ti}_{82} \mathrm{Nb}_{13} \mathrm{Sn}_{5}$ alloys are $6.84 \%$ and $9.46 \%$, respectively, which indicates that the two alloys have a larger elastic strain, as the largest elastic strain is equal to the initial plastic strain. The large elastic strains of $\mathrm{Ti}_{85} \mathrm{Nb}_{10} \mathrm{Sn}_{5}$ and $\mathrm{Ti}_{82} \mathrm{Nb}_{13} \mathrm{Sn}_{5}$ alloys are due to the long time or displacement of martensite transformation for a large number of $\alpha$ or $\alpha^{\prime \prime}$ phases under the action of stress. In addition, the small $\varepsilon_{0.2}$ values of $\mathrm{Ti}_{79} \mathrm{Nb}_{16} \mathrm{Sn}_{5}$ and $\mathrm{Ti}_{75} \mathrm{Nb}_{20} \mathrm{Sn}_{5}$ alloys indicate that the two alloys do not exhibit hyperelastic characteristics. The small elastic strain of $\mathrm{Ti}_{79} \mathrm{Nb}_{16} \mathrm{Sn}_{5}$ alloy is due to the short time or displacement of martensite transformation for a small number of $\alpha^{\prime \prime}$ phases; the elastic strain of $\mathrm{Ti}_{79} \mathrm{Nb}_{16} \mathrm{Sn}_{5}$ alloy is only from the elastic strain of $\beta$ phase. In Figure $4 a, b$, the $\mathrm{Ti}_{85} \mathrm{Nb}_{10} \mathrm{Sn}_{5}$ alloy exhibits an obvious martensite transformation stress platform, which is due to the stress-induced martensite transformation of a large number of $\alpha$ phases. When the relative content of the $\alpha^{\prime \prime}$ phase is low, the stress platform of $\mathrm{Ti}_{82} \mathrm{Nb}_{13} \mathrm{Sn}_{5}$ alloy is not obvious, which is due to the stress-induced martensite transformation of partial $\alpha^{\prime \prime}$ phases. However, when the relative content of $\alpha^{\prime \prime}$ phase was $7 \%$, the stress platform of $\mathrm{Ti}_{79} \mathrm{Nb}_{16} \mathrm{Sn}_{5}$ alloy is not exhibited in Figure 4c, In fact, the elastic-plastic deformation of $\mathrm{Ti}_{79} \mathrm{Nb}_{16} \mathrm{Sn}_{5}$ is larger than that of $\mathrm{Ti}_{75} \mathrm{Nb}_{20} \mathrm{Sn}_{5}$ alloy with the single $\beta$ phase, as shown in Figure $4 \mathrm{c}$,d. The large elastic-plastic deformation is due to the stress-induced martensite transformation of a small number of $\alpha^{\prime \prime}$ phases. Accordingly, the relative contents of $\alpha$ and $\alpha^{\prime \prime}$ phases not only affect the stress platform of martensite transformation, but also affect the elastic-plastic deformation of the alloys.

The $\sigma_{0.2}$ values of $\mathrm{Ti}_{85} \mathrm{Nb}_{10} \mathrm{Sn}_{5}$ and $\mathrm{Ti}_{82} \mathrm{Nb}_{13} \mathrm{Sn}_{5}$ alloys are $787 \mathrm{MPa}$ and $772 \mathrm{MPa}$, respectively, which are larger than those of $\mathrm{Ti}_{79} \mathrm{Nb}_{16} \mathrm{Sn}_{5}(611 \mathrm{MPa})$ and $\mathrm{Ti}_{75} \mathrm{Nb}_{20} \mathrm{Sn}_{5}$ (435 MPa) alloys, respectively. The $\sigma_{0.2}$ values of Ti-Nb-Sn alloys reduce with increased $\mathrm{Nb}$ content. As the martensite transformation of $\alpha$ and $\alpha$ " phases make the $\mathrm{Ti}_{85} \mathrm{Nb}_{10} \mathrm{Sn}_{5}$ and $\mathrm{Ti}_{82} \mathrm{Nb}_{13} \mathrm{Sn}_{5}$ alloys present a two-step yield characteristic, resulting in that the $\sigma_{0.2}$ values of second yield strength are larger than those of $\mathrm{Ti}_{79} \mathrm{Nb}_{16} \mathrm{Sn}_{5}$ and $\mathrm{Ti}_{75} \mathrm{Nb}_{20} \mathrm{Sn}_{5}$ alloys. In addition, as the stress-induced martensite transformation of a small number of $\alpha^{\prime \prime}$ phases for the $\mathrm{Ti}_{79} \mathrm{Nb}_{16} \mathrm{Sn}_{5}$ alloy results in the large elastic-plastic deformation, which make the alloy presents the larger $\sigma_{0.2}$ values, comparing to the $\mathrm{Ti}_{75} \mathrm{Nb}_{20} \mathrm{Sn}_{5}$ alloy. Accordingly, the martensite transformation of $\alpha$ and $\alpha^{\prime \prime}$ phases result in the second yield or elastic-plastic deformation, which affect the yield strength of the Ti-Nb-Sn alloys, or make the yield strength of the alloy decrease with the decrease of martensite contents.

The Vickers hardness (HV) values of $\mathrm{Ti}_{85} \mathrm{Nb}_{10} \mathrm{Sn}_{5}$ and $\mathrm{Ti}_{82} \mathrm{Nb}_{13} \mathrm{Sn}_{5}$ alloys are 230 and 226, respectively, while those of $\mathrm{Ti}_{79} \mathrm{Nb}_{16} \mathrm{Sn}_{5}$ and $\mathrm{Ti}_{75} \mathrm{Nb}_{20} \mathrm{Sn}_{5}$ alloys are 220 and 218, respectively, as shown in Table 1. In fact, in the present $\mathrm{Ti}-\mathrm{Nb}-\mathrm{Sn}$ alloys, the $\mathrm{HV}$ value of $\mathrm{Ti}_{85} \mathrm{Nb}_{10} \mathrm{Sn}_{5}$ alloy is the largest; however, the $\mathrm{Ti}_{75} \mathrm{Nb}_{20} \mathrm{Sn}_{5}$ alloy exhibits the minimum $\mathrm{HV}$ value. Therefore, the content of $\alpha^{\prime \prime}$ martensite phase affects the Vickers hardness of the alloy, and when the content of $\alpha^{\prime \prime}$ martensite phase decreases, the Vickers hardness of the alloys is reduced accordingly.

\subsection{Elastic Energy of $\mathrm{Ti}-\mathrm{Nb}-\mathrm{Sn}$ Alloys}

For the $\mathrm{Ti}_{85} \mathrm{Nb}_{10} \mathrm{Sn}_{5}$ and $\mathrm{Ti}_{82} \mathrm{Nb}_{13} \mathrm{Sn}_{5}$ hyperelastic alloys, the stress-induced martensite transformation can be exhibited in the stress-strain curve, and the cyclic dissipation energy can be calculated under cyclic loading. For the hyperelastic alloys, the calculation of cyclic dissipation energy is more practical than the calculation of elastic energy, so the $\mathrm{Ti}_{85} \mathrm{Nb}_{10} \mathrm{Sn}_{5}$ and $\mathrm{Ti}_{82} \mathrm{Nb}_{13} \mathrm{Sn}_{5}$ alloys were used to calculate the cyclic dissipation energy.

For the $\mathrm{Ti}_{79} \mathrm{Nb}_{16} \mathrm{Sn}_{5}$ and $\mathrm{Ti}_{75} \mathrm{Nb}_{20} \mathrm{Sn}_{5}$ alloys without the stress platform of martensite transition, the calculated elastic energy is more important than the cyclic dissipation energy. As the biomedical materials are usually used in the range of elastic deformation [41,42], the calculated elastic energy of 
biomedical and/or function materials is important to ensure the safety of applied materials. The elastic energy $\left(W_{\mathrm{e}}\right)$ in Figure 5 can be estimated using Equation (5):

$$
W_{\mathrm{e}}=\frac{1}{2} \sigma_{\mathrm{e}} \varepsilon_{\mathrm{e}}
$$

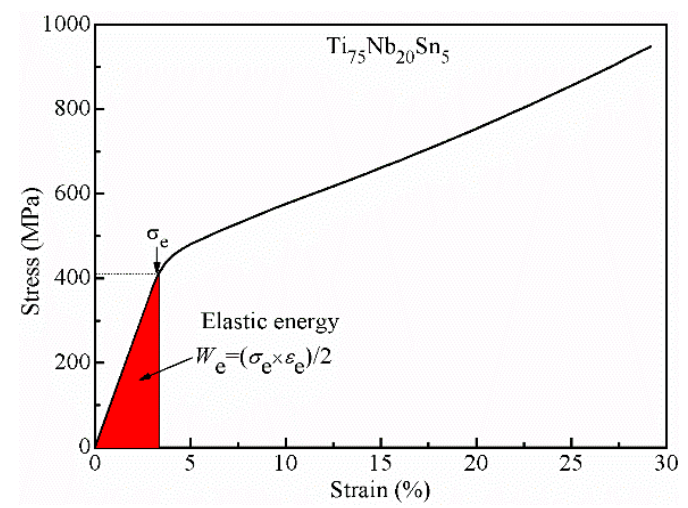

Figure 5. Compression elastic energy of $\mathrm{Ti}_{75} \mathrm{Nb}_{20} \mathrm{Sn}_{5}$ alloy.

The calculated $W_{\mathrm{e}}$ values of Ti-Nb-Sn alloys are list in Table 1 . The elastic energy of $\mathrm{Ti}_{75} \mathrm{Nb}_{20} \mathrm{Sn}_{5}$ alloy is $6.53 \times 10^{6} \mathrm{~J} \cdot \mathrm{m}^{-3}$, which is higher than that of $\mathrm{Ti}_{79} \mathrm{Nb}_{16} \mathrm{Sn}_{5}$ alloy $\left(1.65 \times 10^{6} \mathrm{~J} \cdot \mathrm{m}^{-3}\right)$. In fact, the $W_{\mathrm{e}}$ value of $\mathrm{Ti}_{75} \mathrm{Nb}_{20} \mathrm{Sn}_{5}$ alloy is higher than that of the commercial biomedical material Ti-6Al-4V alloy $\left(2.8 \times 10^{6} \mathrm{~J} \cdot \mathrm{m}^{-3}\right)[17,43]$, which indicates that the $\mathrm{Ti}_{75} \mathrm{Nb}_{20} \mathrm{Sn}_{5}$ alloy can be used as a novel biomedical material.

\subsection{Cyclic Loading Stress-Strain Curves of $\mathrm{Ti}-\mathrm{Nb}-\mathrm{Sn}$ Alloys}

Figure 6 shows the stress-strain curves of $\mathrm{Ti}_{85} \mathrm{Nb}_{10} \mathrm{Sn}_{5}$ and $\mathrm{Ti}_{82} \mathrm{Nb}_{13} \mathrm{Sn}_{5}$ alloys under 10 loading cycles. As the content of $\alpha$ phase for the $\mathrm{Ti}_{85} \mathrm{Nb}_{10} \mathrm{Sn}_{5}$ alloy are larger than that of $\alpha$ "phase for the $\mathrm{Ti}_{82} \mathrm{Nb}_{13} \mathrm{Sn}_{5}$ alloy, the content of martensitic transformation for the former may be larger than that for the latter. Under the same cyclic loading times, the plastic deformation of $\mathrm{Ti}_{85} \mathrm{Nb}_{10} \mathrm{Sn}_{5}$ alloy may also be larger than that of $\mathrm{Ti}_{82} \mathrm{Nb}_{13} \mathrm{Sn}_{5}$ alloy. Accordingly, the set constant strain of $\mathrm{Ti}_{85} \mathrm{Nb}_{10} \mathrm{Sn}_{5}$ alloy can be larger than that of $\mathrm{Ti}_{82} \mathrm{Nb}_{13} \mathrm{Sn}_{5}$ alloy under the cyclic loading. The set constant strain of the two alloys lies in the stress platforms of martensitic transformation in Figure 4a,b. Figure 6 shows that the $\mathrm{Ti}_{85} \mathrm{Nb}_{10} \mathrm{Sn}_{5}$ alloy is cyclic loading at a constant strain of $4.2 \%(<4.48 \%$, seen in Table 1$)$, while the $\mathrm{Ti}_{82} \mathrm{Nb}_{13} \mathrm{Sn}_{5}$ alloy is subjected to cyclic loading at a constant strain of $3.5 \%(<5.56 \%$, seen in Table 1$)$. Based on the stress-strain curve of cyclic loading, $W_{\mathrm{d}}, \varepsilon_{\mathrm{r}}$, the elastic strain $\left(\varepsilon_{\mathrm{e}}\right)$, and the critical stress $\left(\sigma_{\mathrm{m}}\right)$ of stress-induced martensitic tranformation are listed in Table 2.
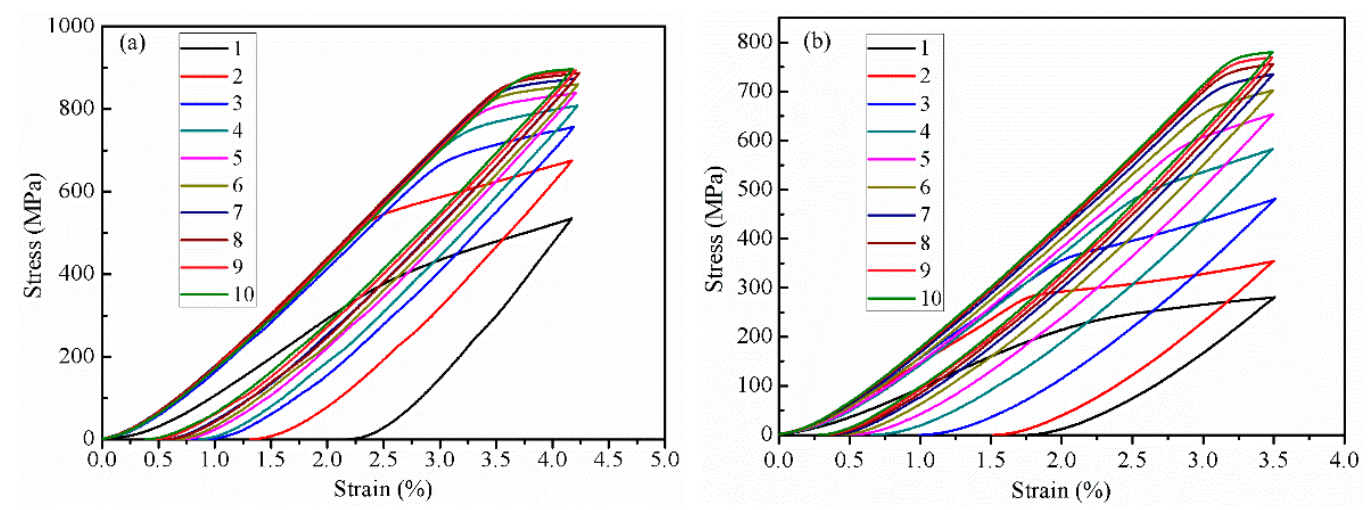

Figure 6. Cyclic loading stress-strain curve of (a) $\mathrm{Ti}_{85} \mathrm{Nb}_{10} \mathrm{Sn}_{5}$ and (b) $\mathrm{Ti}_{82} \mathrm{Nb}_{13} \mathrm{Sn}_{5}$ alloys. 
Table 2. The cyclic dissipation energy $\left(W_{\mathrm{d}}\right)$, residual strain $\left(\varepsilon_{\mathrm{r}}\right)$, elastic strain $\left(\varepsilon_{\mathrm{e}}\right)$, and critical stress $\left(\sigma_{\mathrm{m}}\right)$ of martensitic tranformation.

\begin{tabular}{cccccccccccc}
\hline \multicolumn{1}{c}{ Alloys } & Parameters & $\mathbf{1}$ & $\mathbf{2}$ & $\mathbf{3}$ & $\mathbf{4}$ & $\mathbf{5}$ & $\mathbf{6}$ & $\mathbf{7}$ & $\mathbf{8}$ & $\mathbf{9}$ & $\mathbf{1 0}$ \\
\hline & $W_{\mathrm{d}} \times 10^{6}\left(\mathrm{~J} \cdot \mathrm{m}^{-3}\right)$ & 7.44 & 8.54 & 7.08 & 6.5 & 6.43 & 6.44 & 5.77 & 5.73 & 5.72 & 5.70 \\
$\mathrm{Ti}_{85} \mathrm{Nb}_{10} \mathrm{Sn}_{5}$ & $\varepsilon_{\mathrm{r}}(\%)$ & 2.17 & 1.32 & 0.92 & 0.86 & 0.70 & 0.67 & 0.58 & 0.56 & 0.46 & 0.39 \\
& $\varepsilon_{\mathrm{e}}(\%)$ & 1.47 & 2.09 & 2.55 & 2.64 & 2.87 & 2.90 & 2.93 & 3.00 & 3.04 & 3.05 \\
& $\sigma_{\mathrm{m}}(\mathrm{MPa})$ & 405 & 538 & 684 & 750 & 802 & 829 & 842 & 863 & 872 & 881 \\
& $W_{\mathrm{d}} \times 10^{6}\left(\mathrm{~J} \cdot \mathrm{m}^{-3}\right)$ & 3.82 & 4.97 & 4.84 & 3.95 & 3.25 & 3.28 & 3.13 & 3.13 & 3.13 & 3.13 \\
$\mathrm{Ti}_{82} \mathrm{Nb}_{13} \mathrm{Sn}_{5}$ & $\varepsilon_{\mathrm{r}}(\%)$ & 1.77 & 1.52 & 0.99 & 0.65 & 0.5 & 0.41 & 0.36 & 0.32 & 0.29 & 0.29 \\
& $\varepsilon_{\mathrm{e}}(\%)$ & 1.24 & 1.45 & 1.75 & 1.98 & 2.24 & 2.28 & 2.42 & 2.49 & 2.49 & 2.49 \\
& $\sigma_{\mathrm{m}}(\mathrm{MPa})$ & 227 & 284 & 365 & 492 & 591 & 658 & 710 & 736 & 756 & 766 \\
\hline
\end{tabular}

The $\varepsilon_{\mathrm{e}}$ values of the two alloys increase with the increase in the number of loading times. In fact, the $\varepsilon_{\mathrm{e}}$ values of two alloys increase more quickly before five loading cycles, but the $\varepsilon_{\mathrm{e}}$ values change slightly and tend to be stable after more than five times, as shown in Figure $7 \mathrm{~b}$. The $\varepsilon_{\mathrm{r}}$ values of $\mathrm{Ti}_{85} \mathrm{Nb}_{10} \mathrm{Sn}_{5}$ alloy decrease rapidly before three times, decrease slowly and approximately tend to be stable in the more than third time, as shown in Figure $7 \mathrm{~b}$.
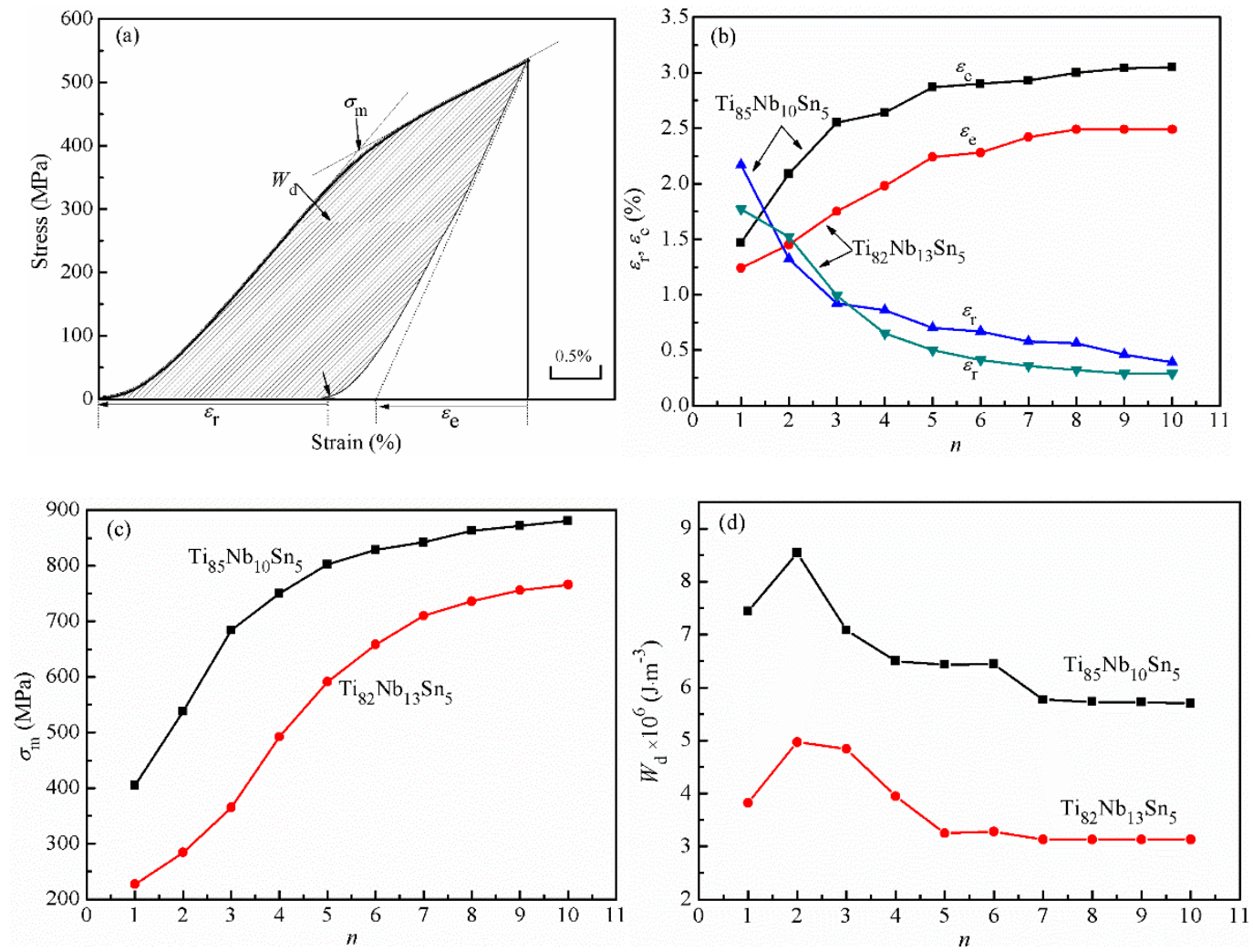

Figure 7. The (a) stress-strain curves of $\mathrm{Ti}_{85} \mathrm{Nb}_{10} \mathrm{Sn}_{5}$ alloy under first cyclic loading; the relationship between, $(\mathbf{b})$ residual strain $\left(\varepsilon_{\mathrm{r}}\right)$ and elastic strain $\left(\varepsilon_{\mathrm{e}}\right),(\mathbf{c})$ critical stress $\left(\sigma_{\mathrm{m}}\right),(\mathbf{d})$ cyclic dissipation energy $\left(W_{\mathrm{d}}\right)$, and loading times $(n)$ for the $\mathrm{Ti}_{85} \mathrm{Nb}_{10} \mathrm{Sn}_{5}$ and $\mathrm{Ti}_{82} \mathrm{Nb}_{13} \mathrm{Sn}_{5}$ alloys.

The $\varepsilon_{\mathrm{r}}$ values of $\mathrm{Ti}_{82} \mathrm{Nb}_{13} \mathrm{Sn}_{3}$ alloy decrease more rapidly before four times; after more than five times, the $\varepsilon_{\mathrm{r}}$ values decrease slowly and tend to be stable, as shown in Figure $7 \mathrm{~b}$. As the residual strain is a performance index of hyperelastic material, the lower the residual strain is, the better the hyperelastic property of the alloy is. The final residual strain values that tend to be stable for the $\mathrm{Ti}_{85} \mathrm{Nb}_{10} \mathrm{Sn}_{5}$ and $\mathrm{Ti}_{82} \mathrm{Nb}_{13} \mathrm{Sn}_{5}$ alloys are $0.39 \%$ and $0.29 \%$, respectively. The stable residual strain indicates that two alloys exhibit better superelastic properties. For superelastic materials, the critical 
stress $\left(\sigma_{\mathrm{m}}\right)$ of stress-induced martensite transformation is an important performance index. Usually, the larger the $\sigma_{\mathrm{m}}$ values is, the greater the constant stress is, which results in that, the smaller the residual strain is, the better the hyperelastic property of the alloy is. During cyclic loading, two alloys presents the $\sigma_{\mathrm{m}}$ values of martensite transformation, and the $\sigma_{\mathrm{m}}$ value increases with the increase of cycle times, and the final $\sigma_{\mathrm{m}}$ values tend to remain stable, as shown in Figure $7 \mathrm{c}$. When the $\sigma_{\mathrm{m}}$ values of two alloys tend to be stable and invariant, the corresponding residual strain is minimum, indicating that two alloys have the good hyperelasticity. When the stress reaches the critical stress $\left(\sigma_{\mathrm{m}}\right)$ of martensitic transformation, martensite transformation occurs, which results in that stress platform with the increase of stress can be exhibited in Figure 6. For the first and second cyclic loading of two alloys, the length of the stress platform of martensitic transformation is relatively large, and the length of the later stress platform decreases with the increase of the loading times, and the length of the final stress platform tends to remain invariant, as shown in Figure 6. When the alloy is unloaded, some of the martensite undergoes an inverse transformation, so the martensitic transformation occurs again when the alloy is reloaded. When loading and unloading reach a certain number of times, the contents of inverse martensitic transformation are approximately constant, which can result in the fact that the stress-platform length and the residual strain tend to be approximately invariant. Due to the loading strain on the stress platform of martensite transformation, some of the martensite is converted to austenite under loading conditions. Under the condition of unloading, only a small amount of martensite has inverse phase transformation, so no stress-induced reverse transformation of martensite can be observed on the unloading stress-strain curve. For the two alloys, the maximum value of cyclic dissipation energy $\left(W_{\mathrm{d}}\right)$ is at the second cycle loading, starting from the second cycle, the $W_{\mathrm{d}}$ values decrease rapidly, and then tends to stabilize, that is, the $W_{\mathrm{d}}$ values of the $\mathrm{Ti}_{85} \mathrm{Nb}_{10} \mathrm{Sn}_{5}$ alloy tend to be stable after the seventh cycle; however, the $W_{\mathrm{d}}$ values of the $\mathrm{Ti}_{82} \mathrm{Nb}_{13} \mathrm{Sn}_{5}$ alloy tend to stabilize after the fifth cycle, as shown in Figure 7d. During the first few cycles of the alloys, the interface of the parent phase is more movable, and its dissipation energy includes not only the energy dissipation generated by the stress-induced $\alpha^{\prime \prime}$ phase transformation, but also the energy dissipation caused by the movement of the parent phase interface [44]. Therefore, in the first few cycles, the energy consumption is large. With the increase of cycle times, the mobility of the parent phase interface becomes poor, and the energy dissipation caused by the movement of the parent phase interface gradually disappears [44], which leads to the decrease of the $W_{\mathrm{d}}$ of the two alloys with the increase of the loading times (larger than the second time). Finally, the $W_{\mathrm{d}}$ values tend to be stable.

\subsection{Nanoindentation of $\mathrm{Ti}-\mathrm{Nb}-\mathrm{Sn}$ Alloys}

Figure 8 shows the representative load $(P)$-displacement $(h)$ nanoindentation curves for the Ti-Nb-Sn alloys. The calculated hardness $(H)$, the reduced elastic modulus $\left(E_{r}\right), H / E_{r}$, and $H^{3} / E_{r}{ }^{2}$ ratio are listed in Table 3. The $E_{r}$ values of $T_{80} \mathrm{Nb}_{10} \mathrm{Sn}_{5}$ and $\mathrm{Ti}_{82} \mathrm{Nb}_{13} \mathrm{Sn}_{5}$ alloys are $80 \mathrm{GPa}$ and $75 \mathrm{GPa}$, respectively, while the $E_{r}$ values of $\mathrm{Ti}_{79} \mathrm{Nb}_{16} \mathrm{Sn}_{5}$ and $\mathrm{Ti}_{75} \mathrm{Nb}_{20} \mathrm{Sn}_{5}$ alloys are $62 \mathrm{GPa}$ and $61 \mathrm{GPa}$, respectively. In fact, the $\mathrm{Ti}_{85} \mathrm{Nb}_{10} \mathrm{Sn}_{5}$ alloy has the largest $E_{r}$ value and hardness value (3.4 GPa), and the $\mathrm{Ti}_{75} \mathrm{Nb}_{20} \mathrm{Sn}_{5}$ alloy has the minimum $\mathrm{E}_{\mathrm{r}}$ value and hardness (2.6 GPa).

Table 3. Measured mechanical properties of $\mathrm{Ti}-\mathrm{Nb}-\mathrm{Sn}$ alloys from the nanoindentation, including hardness $(H)$, reduced elastic modulus $\left(E_{\mathrm{r}}\right), H / E_{\mathrm{r}}$, and $H^{3} / E_{\mathrm{r}}{ }^{2}$.

\begin{tabular}{ccccc}
\hline Alloys & $\boldsymbol{E}_{\mathbf{r}}(\mathrm{GPa})$ & $\boldsymbol{H}(\mathrm{GPa})$ & $\boldsymbol{H} / \boldsymbol{E}_{\mathbf{r}}$ & $\boldsymbol{H}^{\mathbf{3}} / \boldsymbol{E}_{\mathbf{r}} \mathbf{2}^{\mathbf{G P a}}$ \\
\hline $\mathrm{Ti}_{85} \mathrm{Nb}_{10} \mathrm{Sn}_{5}$ & 80 & 3.4 & 0.0425 & 0.0061 \\
$\mathrm{Ti}_{82} \mathrm{Nb}_{13} \mathrm{Sn}_{5}$ & 75 & 2.9 & 0.0387 & 0.0043 \\
$\mathrm{Ti}_{79} \mathrm{Nb}_{16} \mathrm{Sn}_{5}$ & 62 & 2.7 & 0.0435 & 0.0051 \\
$\mathrm{Ti}_{75} \mathrm{Nb}_{20} \mathrm{Sn}_{5}$ & 61 & 2.6 & 0.0426 & 0.0047 \\
\hline
\end{tabular}




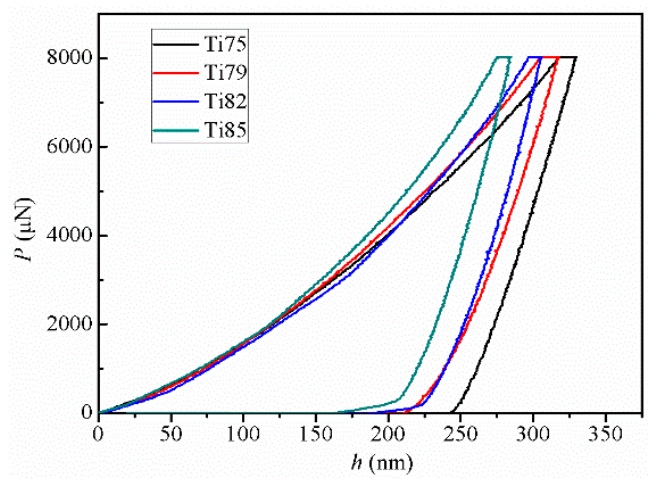

Figure 8. Representative load $(P)$-displacement $(h)$ nanoindentation curves for the Ti-Nb-Sn alloys. The $\mathrm{Ti}_{85} \mathrm{Nb}_{10} \mathrm{Sn}_{5}, \mathrm{Ti}_{82} \mathrm{Nb}_{13} \mathrm{Sn}_{5}, \mathrm{Ti}_{79} \mathrm{Nb}_{16} \mathrm{Sn}_{5}$, and $\mathrm{Ti}_{75} \mathrm{Nb}_{20} \mathrm{Sn}_{5}$ alloys are labeled by Ti85, Ti82, Ti79 and Ti75, respectively.

The $H$ and $E_{\mathrm{r}}$ values decrease with the increase of $\mathrm{Nb}$ content, and with the decrease of martensite contents, as shown in Figure 9a and Table 1. As the elastic modulus and hardness of $\alpha$ or $\alpha^{\prime \prime}$ martensite phase are higher than those of $\beta$ phase, respectively, it indicates that the elastic modulus and hardness of the $\mathrm{Ti}_{85} \mathrm{Nb}_{10} \mathrm{Sn}_{5}$ and $\mathrm{Ti}_{82} \mathrm{Nb}_{13} \mathrm{Sn}_{5}$ alloys are larger than those of the $\mathrm{Ti}_{79} \mathrm{Nb}_{16} \mathrm{Sn}_{5}$ and $\mathrm{Ti}_{75} \mathrm{Nb}_{20} \mathrm{Sn}_{5}$ alloys. In addition, the elastic modulus of the $\mathrm{Ti}_{75} \mathrm{Nb}_{20} \mathrm{Sn}_{5}$ alloy is 2-6 times of that of human bone (10-30 GPa), which is closer to that of human bone, comparing with that of Ti-6Al-4V alloy (120 GPa) [2]. Accordingly, the $\mathrm{Ti}_{75} \mathrm{Nb}_{20} \mathrm{Sn}_{5}$ alloy can be considered as a novel biomedical alloy.
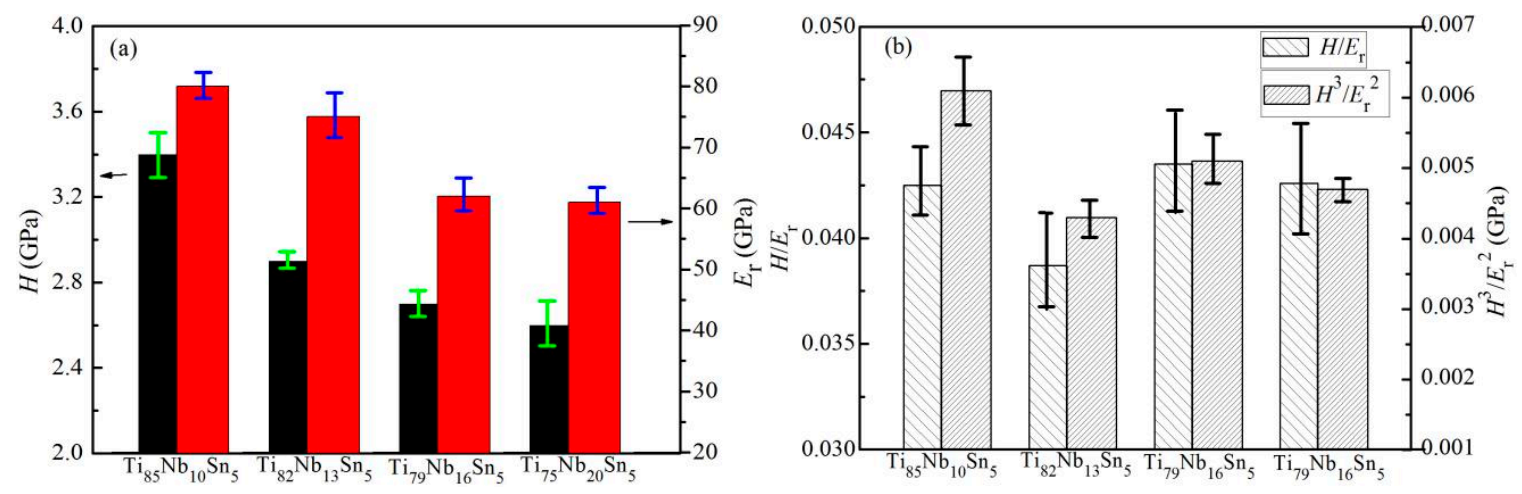

Figure 9. (a) The hardness $(H)$ and reduced elastic modulus $\left(E_{\mathrm{r}}\right)$, and $(\mathbf{b})$ the $H / E_{\mathrm{r}}$ and $H^{3} / E_{\mathrm{r}}{ }^{2}$ ratios of the as-cast $\mathrm{Ti}-\mathrm{Nb}-\mathrm{Sn}$ alloys.

The reported $H / E_{\mathrm{r}}$ value represents the wear resistance of the materials [45]. The large $H / E_{\mathrm{r}}$ value of the materials indicates the large wear resistance of the materials or a long service life [45]. The $\mathrm{Ti}_{79} \mathrm{Nb}_{16} \mathrm{Sn}_{5}$ alloy has the largest $H / E_{\mathrm{r}}$ value (0.0435), and the $\mathrm{Ti}_{82} \mathrm{Nb}_{13} \mathrm{Sn}_{5}$ alloy has the smallest $H / E_{\mathrm{r}}$ value (0.0387), as shown in Figure 9 and Table 3, indicating that the $\mathrm{Ti}_{79} \mathrm{Nb}_{16} \mathrm{Sn}_{5}$ alloy has good wear resistance, and that the $\mathrm{Ti}_{82} \mathrm{Nb}_{13} \mathrm{Sn}_{5}$ alloy has poor wear resistance. In addition, the $H / E_{\mathrm{r}}$ value of $\mathrm{Ti}_{85} \mathrm{Nb}_{10} \mathrm{Sn}_{5}$ alloy is approximately equal to that of $\mathrm{Ti}_{75} \mathrm{Nb}_{20} \mathrm{Sn}_{5}$ alloy, which indicates that there is no direct relationship between the martensite content and the $H / E_{\mathrm{r}}$ values of Ti-Nb-Sn alloys. In addition, the $H / E_{\mathrm{r}}$ values of the four alloys are higher than those of the CP-Ti alloy (0.0238), of the Ti-8Fe alloy, and of the Ti-Fe-Ta alloys [45], which indicates that the Ti-Nb-Sn alloys have the good wear resistance or a long service life as biomedical materials.

Another parameter, the $H^{3} / E_{\mathrm{r}}^{2}$ value, can indicate the anti-wear ability of materials. A large $H^{3} / E_{\mathrm{r}}^{2}$ value indicates a strong anti-wear ability of a material, and thus the service life of the materials can be improved [46,47]. The $\mathrm{Ti}_{85} \mathrm{Nb}_{10} \mathrm{Sn}_{5}$ alloy has the largest $H^{3} / E_{\mathrm{r}}{ }^{2}$ value $(0.0061 \mathrm{GPa})$, and the $\mathrm{Ti}_{82} \mathrm{Nb}_{13} \mathrm{Sn}_{5}$ alloy has the smallest $H^{3} / E_{\mathrm{r}}^{2}$ value $(0.0043 \mathrm{GPa})$ in Ti-Nb-Sn alloys, as shown in Figure $9 \mathrm{~b}$ and Table 3 , indicating that the $\mathrm{Ti}_{85} \mathrm{Nb}_{10} \mathrm{Sn}_{5}$ alloy has good anti-wear ability, while the $\mathrm{Ti}_{82} \mathrm{Nb}_{13} \mathrm{Sn}_{5}$ 
alloy has a weak anti-wear ability. In addition, the $H^{3} / E_{\mathrm{r}}^{2}$ values of the $\mathrm{Ti}_{79} \mathrm{Nb}_{16} \mathrm{Sn}_{5}$ and $\mathrm{Ti}_{75} \mathrm{Nb}_{20} \mathrm{Sn}_{5}$ alloys are $0.0051 \mathrm{GPa}$ and $0.0047 \mathrm{GPa}$, respectively, but smaller than that of $\mathrm{Ti}_{85} \mathrm{Nb}_{10} \mathrm{Sn}_{5}$ alloy, and larger than that of $\mathrm{Ti}_{82} \mathrm{Nb}_{13} \mathrm{Sn}_{5}$ alloy. These results indicate that there is no direct relationship between the content of $\alpha^{\prime \prime}$ martensite phase and the $H^{3} / E_{\mathrm{r}}{ }^{2}$ values of alloys, which is similar to the results of $H / E_{\mathrm{r}}$ values. In fact, the $H^{3} / E_{\mathrm{r}}^{2}$ values of Ti-Nb-Sn alloys are higher than that of CP-Ti biomaterial (0.0014 GPa) [45], indicating that the Ti-Nb-Sn alloys exhibit the good anti-wear capability or long service life as biomedical materials.

\section{Conclusions}

The microstructural and mechanical properties of $\beta$-type $\operatorname{Ti}_{85-\mathrm{x}} \mathrm{Nb}_{10-\mathrm{x}} \mathrm{Sn}_{5}(\mathrm{x}=0,3,6,10$ at.\%) alloys with low Young's modulus were investigated. The main results are summarized as follows:

(1) The $\mathrm{Ti}_{85} \mathrm{Nb}_{10} \mathrm{Sn}_{5}$ and $\mathrm{Ti}_{75} \mathrm{Nb}_{20} \mathrm{Sn}_{5}$ alloys are composed of simple $\alpha$ and $\beta$ phase, respectively; the $\mathrm{Ti}_{82} \mathrm{Nb}_{13} \mathrm{Sn}_{5}$ and $\mathrm{Ti}_{79} \mathrm{Nb}_{16} \mathrm{Sn}_{5}$ alloys are composed of $\beta$ and $\alpha^{\prime \prime}$ phases. The content of martensite phase decreases with the increase of $\mathrm{Nb}$ content.

(2) The $\mathrm{Ti}_{82} \mathrm{Nb}_{13} \mathrm{Sn}_{5}$ and $\mathrm{Ti}_{79} \mathrm{Nb}_{16} \mathrm{Sn}_{5}$ alloys show inverse martensitic phase transition during heating. No martensite phase transition is found during cooling from $150{ }^{\circ} \mathrm{C}$ to $-100{ }^{\circ} \mathrm{C}$. The Ti-Nb-Sn alloys with no martensitic transformation in the temperature range that human body can bear can be considered as the good biomedical alloy for implantation.

(3) The final residual strain values that tend to be stable for the $\mathrm{Ti}_{85} \mathrm{Nb}_{10} \mathrm{Sn}_{5}$ and $\mathrm{Ti}_{82} \mathrm{Nb}_{13} \mathrm{Sn}_{5}$ alloys are $0.39 \%$ and $0.29 \%$, respectively, indicating the good superelastic properties of the alloys in 10-times cyclic loading.

(4) The reduced elastic modulus of $\mathrm{Ti}_{75} \mathrm{Nb}_{20} \mathrm{Sn}_{5}$ alloy is $61 \mathrm{GPa}$, which is 2-6 times of that of human bone (10-30 GPa), and is smaller than that of commercial Ti-6Al-4V biomedical alloy (120 GPa). The $\mathrm{Ti}_{75} \mathrm{Nb}_{20} \mathrm{Sn}_{5}$ alloy can be considered as a novel biomedical alloy. The $H / E_{\mathrm{r}}$ and $H^{3} / E_{\mathrm{r}}{ }^{2}$ values of the four alloys are higher than those of the CP-Ti alloy (0.0238), which indicates that the presented alloys have good wear resistance and anti-wear capability.

Author Contributions: P.L. and X.M. conceived and designed the experiments; P.L., X.M. and D.W. performed the experiments, analyzed the data, wrote original draft preparation; P.L. and H.Z. wrote review and editing.

Conflicts of Interest: The authors declare no conflict of interest.

\section{References}

1. Liu, Y.J.; Li, X.P.; Zhang, L.C.; Sercombe, T.B. Processing and properties of topologically optimised biomedical Ti-24Nb-4Zr-8Sn scaffolds manufactured by selective laser melting. Mater. Sci. Eng. A 2015, 642, $268-278$. [CrossRef]

2. Ninomi, M. Recent metallic materials for biomedical applications. Metall. Mater. Trans. A 2002, 33A, 477-486. [CrossRef]

3. Song, B.; Dong, S.J.; Zhang, B.C.; Liao, H.L.; Coddet, C. Effects of processing parameters on microstructure and mechanical property of selective laser melted Ti6Al4V. Mater. Des. 2012, 35, 120-125. [CrossRef]

4. Chaves, J.M.; Florêncio, O.; Silva, P.S.; Marques, P.W.B.; Afonso, C.R.M. Influence of phase transformations on dynamical elastic modulus and anelasticity of beta $\mathrm{Ti}-\mathrm{Nb}-\mathrm{Fe}$ alloys for biomedical applications. J. Mech. Behav. Biomed. Mater. 2015, 46, 184-196. [CrossRef]

5. Niinomi, M. Recent research and development in titanium alloys for biomedical applications and healthcare goods. Sci. Technol. Adv. Mater. 2003, 4, 445-454. [CrossRef]

6. Hon, Y.H.; Wang, J.Y.; Pan, Y.N. Composition/phase structure and properties of Titanium-Niobium alloys. Mater. Trans. 2003, 44, 2384-2390. [CrossRef]

7. Li, P.Y. Microstructural and mechanical properties of novel $\beta$-type $\mathrm{Ti}-\mathrm{Nb}-\mathrm{Ni}$ alloys containing a second phase. Int. J. Mater. Res. 2018, 109, 708-715. [CrossRef]

8. Ozaki, T.; Matsumoto, H.; Watanabe, S.; Hanada, S. Beta Ti alloys with low Young's modulus. Mater. Trans. 2004, 45, 2776-2779. [CrossRef] 
9. Matsumoto, H.; Watanable, S.; Hanada, S. Beta TiNbSn alloys with low Young's modulus and high strength. Mater. Trans. 2005, 46, 1070-1078. [CrossRef]

10. Moraes, P.E.L.; Contieri, R.J.; Lopes, E.S.N.; Robin, A.; Caram, R. Effects of Sn addition on the microstructure, mechanical properties and corrosion behavior of Ti-Nb-Sn alloys. Mater. Charact. 2014, 96, 273-281. [CrossRef]

11. Attar, H.; Haghighi, S.E.; Kent, D.; Wu, X.H.; Dargusch, M.S. Comparative study of commercially pure titanium produced by laser engineered net shaping, selective laser melting and casting processes. Mater. Sci. Eng. A 2017, 705, 385-393. [CrossRef]

12. Ho, W.F.; Wu, S.C.; Hsu, S.K.; Li, Y.C.; Hsu, H.C. Effects of molybdenum content on the structure and mechanical properties of as-cast Ti-10Zr-based alloys for biomedical applications. Mater. Sci. Eng. C 2012, 32, 517-522. [CrossRef]

13. Ho, W.F.; Pan, C.H.; Wu, S.C.; Hsu, H.C. Mechanical properties and deformation behavior of Ti-5Cr-xFe alloys. J. Alloys Compd. 2009, 472, 546-550. [CrossRef]

14. Silva, H.; Schneider, S.; Neto, C.M. Study of nontoxic aluminum and vanadium-free titanium alloys for biomedical applications. Mater. Sci. Eng. C 2004, 24, 679-682. [CrossRef]

15. Hsu, H.C.; Hsu, S.K.; Wu, S.C.; Lee, C.J.; Ho, W.F. Structure and mechanical properties of as-cast Ti-5Nb-xFe alloys. Mater. Charact. 2010, 61, 851-858. [CrossRef]

16. Chang, L.L.; Wang, Y.D.; Ren, Y. In-situ investigation of stress-induced martensitic transformation in Ti-Nb binary alloys with low Young's modulus. Mater. Sci. Eng. A 2016, 651, 442-448. [CrossRef]

17. Haghighi, S.E.; Liu, Y.J.; Cao, G.H.; Zhang, L.C. Phase transition, microstructural evolution and mechanical properties of Ti-Nb-Fe alloys induced by Fe addition. Mater. Des. 2016, 97, 279-286. [CrossRef]

18. Haghighi, S.E.; Prashanth, K.G.; Attar, H.; Chaubey, A.K.; Cao, G.H.; Zhang, L.C. Evalution of mechanical and wear properties of $\mathrm{Ti}-\mathrm{xNb}-7 \mathrm{Fe}$ alloys disinged for biomedical applications. Mater. Des. 2016, 111, 592-599. [CrossRef]

19. Wen, M.; Wen, C.; Hodgson, P.; Li, Y. Fabrication of Ti-Nb-Ag alloy via powder metallurgy for biomedical applications. Mater. Des. 2014, 56, 629-634. [CrossRef]

20. Xu, W.; Kim, K.B.; Das, J.; Calin, M.; Eckert, J. Phase stability and its effffect on the deformation behavior of Ti-Nb-Ta-In/Cr b alloys. Scr. Mater. 2006, 54, 1943-1948. [CrossRef]

21. Haghighi, S.E.; Liu, Y.J.; Cao, G.H.; Zhang, L.C. Influence of $\mathrm{Nb}$ on the $\beta \rightarrow \alpha$ " martensitic phase transformation and properties of the newly designed Ti-Fe-Nb alloys. Mater. Sci. Eng. C 2017, 60, 503-510. [CrossRef]

22. Li, P.Y.; Zhang, H.; Tong, T.; He, Z.R. The rapidly solidified $\beta$-type Ti-Fe-Sn alloys with high specific strength and low elastic modulus. J. Alloys Compd. 2019, 786, 986-994. [CrossRef]

23. Nnamchi, P.S.; Obayi, C.S.; Todd, I.; Rainforth, M.W. Mechanical and electrochemical characterisation of new Ti-Mo-Nb-Zr alloys for biomedical applications. J. Mech. Behav. Biomed. Mater. 2016, 60, 68-77. [CrossRef]

24. Ruzic, J.; Emura, X.; Ji, X.; Watanabe, I. Mo segregation and distribution in Ti-Mo alloy investigated using nanoindentation. Mater. Sci. Eng. A 2018, 718, 48-55. [CrossRef]

25. Biesiekierski, A.; Lin, J.X.; Li, Y.C.; Ping, D.H.; Yamabe-Mitarai, Y.; Wen, C. Investigations into Ti-(Nb, Ta)-Fe alloys for biomedical application. Acta Biomater. 2016, 32, 336-347. [CrossRef]

26. Pavón, L.L.; Kim, H.Y.; Hosoda, H.; Miyazaki, S. Effect of Nb content and heat treatment temperature on superelastic properties of Ti-24Zr-(8-12)Nb-2Sn alloys. Scripta Mater. 2015, 95, 46-49. [CrossRef]

27. Qu, W.T.; Sun, X.G.; Yuan, B.F.; Xiong, C.Y.; Zhang, F.; Li, Y.; Sun, B.H. Microstructures and phase transformations of Ti-30Zr-xNb ( $x=5,7,9,13$ at.\%) shape memory alloys. Mater. Charact. 2016, 122, 1-5. [CrossRef]

28. Kim, H.Y.; Ikehara, Y.; Kim, J.I.; Hosoda, H.; Miyazaki, S. Martensitic transformation, shape memory effect and superelasticity of Ti-Nb binary alloys. Acta Mater. 2006, 54, 2419-2429. [CrossRef]

29. Zhang, D.C.; Lin, J.G.; Jiang, W.J.; Ma, M.; Peng, Z.G. Shape memory and superelastic behavior of Ti-7.5Nb-4Mo-1Sn alloy. Mater. Des. 2011, 32, 4614-4617. [CrossRef]

30. Horiuchi, Y.; Nakayama, K.; Inamura, T.; Kim, H.Y.; Wakashima, K.; Miyazaki, S.; Hosoda, H. Effect of Cu addition on shape memory behavior of Ti-18 mol\%Nb alloys. Mater. Trans. 2007, 48, 414-421. [CrossRef]

31. Wang, B.L.; Zheng, Y.F.; Zhao, L.C. Effects of Sn content on the microstructure, phase constitution and shape memory effect of Ti-Nb-Sn alloys. Mater. Sci. Eng. A 2008, 486, 146-151. [CrossRef]

32. Kim, J.I.; Kim, H.Y.; Hosoda, H.; Miyazaki, S. Shape memory characteristics of Ti-22Nb-(2-8)Zr (at.\%) biomedical alloys. Mater. Sci. Eng. A 2005, 403, 334-339. [CrossRef] 
33. Yılmaz, E.; Gökçe, A.; Findik, F.; Gülsoy, H.O. Characterization of biomedical Ti-16Nb-(0-4) Sn alloys produced by powder injection molding. Vacuum 2017, 142, 164-174.

34. Guo, S.; Shang, Y.; Zhang, J.S.; Meng, Q.K.; Cheng, X.N.; Zhao, X.Q. In situ synchrotron X-ray diffraction study of deformation behaviour of a metastable $\beta$-type Ti-33Nb-4Sn alloy. Mater. Sci. Eng. A 2017, 692, 81-89. [CrossRef]

35. Hanada, S.; Masahashi, N.; Jung, T.K.; Yamada, N.; Yamako, G.; Itoi, E. Fabrication of a high-performance hip prosthetic stem using $\beta$ Ti-33.6Nb-4Sn. J. Mech. Behav. Biomed. Mater. 2014, 30, 140-149. [CrossRef]

36. Miura, K.K.; Yamada, N.; Hanada, S.J.; Jung, T.K.; Itoi, E. The bone tissue compatibolity of a new Ti-Nb-Sn alloy with low Young's modulus. Acta. Biomater. 2011, 7, 2320-2326. [CrossRef]

37. Li, P.Y. Microstructure and mechanical properties of novel $\beta$-type Ti-Co-Zr alloys with high specific strength. Mater. Res. Express 2019, 6, 076559. [CrossRef]

38. Yang, H.; Wen, J.; Quan, M.; Wang, J. Evaluation of the volume fraction of nanocrystals devitrified in Al-based amorphous alloys. J. Non-Cryst. Solids 2009, 355, 235-238. [CrossRef]

39. Kolli, R.P.; Joost, W.J.; Ankem, S. Phase stability and stress-induced transformation in beta Titanium alloys. JOM 2015, 67, 1273-1280. [CrossRef]

40. Wang, Q.; Dong, C.; Liaw, P.K. Structural stabilities of $\beta$-Ti alloys studied using a new Mo equivalent derived from $[\beta /(\alpha+\beta)]$ phase-boundary slopes. Metall. Mater. Trans. A 2015, 46, 3440-3447. [CrossRef]

41. Cui, B.; Yao, J.; Wu, Y.; Zhang, X.; Wang, F.L.; Sui, J.H.; Cai, W. Precipitation behavior and mechanical properties of Ti-Ni-Nb-Co alloys. Intermetallics 2018, 95, 40-47. [CrossRef]

42. Hussein, A.H.; Gepreel, M.A.H.; Gouda, M.K.; Hefnawy, A.M.; Kandil, S.H. Biocompatibility of new Ti-Nb-Ta base alloys. Mater. Sci. Eng. C 2016, 61, 574-578. [CrossRef]

43. Fischer, F.D.; Reisner, G.; Werner, E.; Tanaka, K.; Cailletaud, G.; Antretter, T. A new view on transformation induced plasticity (TRIP). Int. J. Plast. 2000, 16, 723-748. [CrossRef]

44. He, Z.R.; Wang, Q.; Wang, F.; Wang, Y.S.; Yang, J. Effect of annealing temperatures on microstructure and tensile properties of Ti-Ni-Cr low-temperature superelasticity alloy. Rare Met. Mater. Eng. 2011, 40, 1998-2001.

45. Haghighi, S.E.; Cao, G.H.; Zhang, L.C. Nanoindentation study of mechanical properities of Ti based alloys with Fe and Ta additions. J. Alloys Compds. 2017, 692, 892-897. [CrossRef]

46. Xu, J.; Wang, G.D.; Lu, X.; Liu, L.; Munroe, P.; Xie, Z.H. Mechanical and corrosion-resistant properties of $\mathrm{Ti}-\mathrm{Nb}-\mathrm{Si}-\mathrm{N}$ nanocomposite films prepared by a double glow discharge plasma technique. Ceram. Int. 2014, 40, 8621-8630. [CrossRef]

47. Musil, J.; Kunc, F.; Zeman, H.; Poláková, H. Relationships between hardness, Young's modulus and elastic recovery in hard nanocomposite coatings. Surf. Coat. Technol. 2002, 154, 304-313. [CrossRef] 